\title{
Downregulation of Spermine Augments Dendritic Persistent Sodium Currents and Synaptic Integration after Status Epilepticus
}

\author{
Michel Royeck, ${ }^{1 *}$ Tony Kelly, ${ }^{1 *}$ Thoralf Opitz, ${ }^{1 *}$ David-Marian Otte, ${ }^{2}$ Andreas Rennhack, ${ }^{3}$ Anne Woitecki, ${ }^{4}$ \\ Julika Pitsch, ${ }^{4}$ Albert Becker, ${ }^{4}$ Susanne Schoch, ${ }^{4}$ Ulrich Benjamin Kaupp, ${ }^{3}{ }^{\circ}$ Yoel Yaari, ${ }^{5}$ Andreas Zimmer, ${ }^{2}$ and \\ Heinz Beck ${ }^{1,6}$ \\ ${ }^{1}$ Laboratory for Experimental Epileptology and Cognition Research, Department of Epileptology, and ${ }^{2}$ Institute of Molecular Psychiatry, University of \\ Bonn, D-53105 Bonn, Germany, ${ }^{3}$ Department of Molecular Sensory Systems, Center of Advanced European Studies and Research, D-53175 Bonn, Germany, \\ ${ }^{4}$ Department of Neuropathology, University of Bonn, D-53105 Bonn, Germany, ${ }^{5}$ Department of Medical Neurobiology, IMRIC, Hebrew \\ University-Hadassah School of Medicine, Jerusalem 91120, Israel, and ${ }^{6}$ Deutsches Zentrum für Neurodegenerative Erkrankungen e.V., 53175 Bonn, \\ Germany
}

Dendritic voltage-gated ion channels profoundly shape the integrative properties of neuronal dendrites. In epilepsy, numerous changes in dendritic ion channels have been described, all of them due to either their altered transcription or phosphorylation. In pilocarpinetreated chronically epileptic rats, we describe a novel mechanism that causes an increased proximal dendritic persistent $\mathrm{Na}^{+}$current $\left(I_{\mathrm{NaP}}\right)$. We demonstrate using a combination of electrophysiology and molecular approaches that the upregulation of dendritic $I_{\mathrm{NaP}}$ is due to a relief from polyamine-dependent inhibition. The polyamine deficit in hippocampal neurons is likely caused by an upregulation of the degrading enzyme spermidine/spermine acetyltransferase. Multiphoton glutamate uncaging experiments revealed that the increase in dendritic $I_{\mathrm{NaP}}$ causes augmented dendritic summation of excitatory inputs. These results establish a novel post-transcriptional modification of ion channels in chronic epilepsy and may provide a novel avenue for treatment of temporal lobe epilepsy.

Key words: epilepsy; persistent sodium current; polyamines; sodium channels; spermine; synaptic integration

Significance Statement

In this paper, we describe a novel mechanism that causes increased dendritic persistent $\mathrm{Na}^{+}$current. We demonstrate using a combination of electrophysiology and molecular approaches that the upregulation of persistent $\mathrm{Na}^{+}$currents is due to a relief from polyamine-dependent inhibition. The polyamine deficit in hippocampal neurons is likely caused by an upregulation of the degrading enzyme spermidine/spermine acetyltransferase. Multiphoton glutamate uncaging experiments revealed that the increase in dendritic persistent Na current causes augmented dendritic summation of excitatory inputs. We believe that these results establish a novel post-transcriptional modification of ion channels in chronic epilepsy.

\section{Introduction}

Individual nerve cells receive tens of thousands of excitatory synapses. The integration of complex temporal and spatial input pat-

Received Feb. 4, 2015; revised Aug. 14, 2015; accepted Sept. 11, 2015.

Author contributions: A.B., S.S., Y.Y., and H.B. designed research; M.R., T.K., T.O., D.-M.O., A.W., and J.P. performed research; A.R. and U.B.K. contributed unpublished reagents/analytic tools; M.R., T.K., T.O., D.-M.O., A.W., J.P., and H.B. analyzed data; M.R., T.K., T.O., A.R., J.P., Y.Y., A.Z., and H.B. wrote the paper.

This work was supported by Deutsche Forschungsgemeinschaft SFB 1089 to H.B., U.B.K., A.B., and S.S., FOR 928 to H.B., Deutsche Forschungsgemeinschaft DIP to Y.Y. and H.B., Nationales Genomforschungsnetzwerk NGFN plus EmiNet, EPICURE coordinated by the Deutsche Luft und Raumfahrt to H.B., German Ministry of Research and Education BMBF, 01 GQ0806 to S.S., and the BONFOR program of the University of Bonn Medical Center. We thank Karen van Loo and Tobias Mittelstaedt for sharing experimental expertise.

The authors declare no competing financial interests.

*M.R., T.K., and T.0. contributed equally to this work. terns arising from this multitude of synaptic contacts, and how these are converted to an action potential output, is arguably the most important characteristic of neuronal function in the context of a network. The integrative properties of neuronal dendrites are profoundly shaped by the domain-specific expression of voltage-gated ion channels (Johnston et al., 1996; Magee, 2000; Spruston, 2008). For instance, in hippocampal pyramidal neurons, highly regulated gradients of A-type $\mathrm{K}^{+}$channels, hyperpolarization-activated cation

Correspondence should be addressed to Dr. Heinz Beck, Laboratory for Cognition Research and Experimenta Epileptology, Department of Epileptology, University of Bonn, Sigmund-Freud Strasse 25, 53105 Bonn, Germany. E-mail: Heinz.beck@ukb.uni-bonn.de.

DOl:10.1523/JNEUROSCI.0493-15.2015

Copyright $\odot 2015$ the authors $\quad 0270-6474 / 15 / 3515240-14 \$ 15.00 / 0$ 
$\left(I_{\mathrm{h}}\right)$ channels, or voltage-gated $\mathrm{Ca}^{2+}$ channels are observed (Beck and Yaari, 2008; Spruston, 2008). Direct recordings from apical dendrites have established the crucial role of these channels in regulating the integration of subthreshold synaptic potentials (Johnston et al., 1996; Häusser et al., 2000; Magee, 2000; Spruston, 2008). In addition, dendritic voltage-gated channels are important in mediating supralinear dendritic integration via the generation of dendritic spikes, regenerative depolarizations triggered by strong, correlated synaptic inputs (Losonczy and Magee, 2006; Remy et al., 2009).

In epilepsy, numerous changes in dendritic ion channel function have been described in CA1 neurons. These include increases in T-type $\mathrm{Ca}^{2+}$ currents, as well as decreased A-type $\mathrm{K}^{+}$currents and $I_{\mathrm{h}}$ (Beck and Yaari, 2008). These changes profoundly affect dendritic integration of excitatory inputs and neuronal inputoutput properties. Consequently, considerable attention has focused on potential mechanisms underlying the regulation of dendritic voltage-gated ion channels. A reduction of dendritic A-type $\mathrm{K}^{+}$currents is caused by both an increased phosphorylation of the underlying $\mathrm{K}_{\mathrm{v}} 4.2$ channels and a marked transcriptional downregulation of $\mathrm{K}_{\mathrm{v}} 4.2$ subunits (Bernard et al., 2004). An increase in dendritic T-type $\mathrm{Ca}^{2+}$ currents is attributed to a transcriptional upregulation of $\mathrm{Ca}_{\mathrm{v}} 3.2$ subunits (Su et al., 2002; Yaari et al., 2007; Becker et al., 2008). Finally, the powerful downregulation of $I_{\mathrm{h}}$ found in hippocampal pyramidal neurons (Jung et al., 2007) and entorhinal cortex neurons (Shah et al., 2004) is due to a marked downregulation of the protein and mRNA levels of HCN subunits, as well as altered phosphorylation (Jung et al., $2007,2010,2011)$. These studies support the view that induction of epilepsy leads to a complex pattern of gene regulation, which in turn causes specific changes in dendritic ion channels. Accordingly, the term "transcriptional channelopathy" has been coined to set these acquired changes apart from other types of channelopathies, for instance, those caused by mutations of ion channel genes.

Here, we describe a novel mechanism that alters dendritic integration in chronic epilepsy. We demonstrate, using a combination of electrophysiological and molecular approaches, that the proximal dendritic persistent $\mathrm{Na}^{+}$current $\left(I_{\mathrm{NaP}}\right)$ is upregulated in chronic epilepsy and that this is due to a relief from polyamine-dependent inhibition. The polyamine deficit in hippocampal neurons is likely caused by an upregulation of the degrading enzyme spermidine/spermine acetyltransferase (SSAT). Multiphoton glutamate uncaging experiments revealed that relief of $I_{\mathrm{NaP}}$ from polyamine-dependent inhibition enhances the summation of dendritic inputs.

\section{Materials and Methods}

Induction of status epilepticus (SE). All animal experiments were conducted in accordance with the guidelines of the Animal Care Committee of the University of Bonn Medical Center. Male Wistar rats (200-230 g) were housed under a $12 \mathrm{~h}$ light-dark cycle with food and water ad libitum. Rats were injected with a single high dose of the muscarinic agonist pilocarpine (340 mg/kg i.p.; Sigma-Aldrich), which induced SE in most animals (Turski et al., 1983; Sanabria et al., 2001). Peripheral muscarinic effects were reduced by prior administration of methylscopolamine ( $1 \mathrm{mg} / \mathrm{kg}$ i.p.; Sigma-Aldrich) $30 \mathrm{~min}$ before injecting pilocarpine. Diazepam ( $20 \mathrm{mg} / \mathrm{kg}$ s.c.; Ratiopharm) was administered to all animals $40 \mathrm{~min}$ after the start of SE. It terminated the convulsions in the responsive rats and sedated all animals. Within $24 \mathrm{~h}$ after pilocarpine injection, the rats appeared behaviorally normal and were kept in single cages until they were killed for experimentation. Sham-control animals were treated exactly as the pilocarpine-treated animals, but the pilocarpine injection was omitted.

Preparation of hippocampal slices. Slices were prepared from animals 11-20 d after pilocarpine or sham treatment. Rats were perfused through the heart with ice-cold sucrose-based artificial CSF (sucrose-ACSF) con- taining the following (in $\mathrm{mm}$ ): $56 \mathrm{NaCl}, 100$ sucrose, $2.5 \mathrm{KCl}, 1.25$ $\mathrm{NaH}_{2} \mathrm{PO}_{4}, 30 \mathrm{NaHCO}_{3}, 1 \mathrm{CaCl}_{2}, 5 \mathrm{MgCl}_{2}$, and 20 D-glucose (pH 7.4 when saturated with $95 \% \mathrm{O}_{2} / 5 \% \mathrm{CO}_{2}, 305 \mathrm{mOsmol} / \mathrm{kg}$ ) under deep anesthesia with ketamine $(100 \mathrm{mg} / \mathrm{kg}$, Pfizer, ) and xylazine $(15 \mathrm{mg} / \mathrm{kg}$, Bayer). After complete perfusion, rats were decapitated, the brain was quickly removed, and 300- $\mu$ m-thick transverse hippocampal slices were cut with a vibratome (HM $650 \mathrm{~V}$, Microm). Slices were then warmed to $35^{\circ} \mathrm{C}$ for $30 \mathrm{~min}$ in sucrose-ACSF and eventually transferred to a holding chamber at room temperature with ACSF containing the following (in mM): $125 \mathrm{NaCl}, 3.5 \mathrm{KCl}, 1.25 \mathrm{NaH}_{2} \mathrm{PO}_{4}, 2 \mathrm{MgCl}_{2}, 2 \mathrm{CaCl}_{2}, 26 \mathrm{NaHCO}_{3}$, and 15 D-glucose $\left(\mathrm{pH} 7.4\right.$ when saturated with $95 \% \mathrm{O}_{2} / 5 \% \mathrm{CO}_{2}, 305$ $\mathrm{mOsmol} / \mathrm{kg}$ ).

Electrophysiology: voltage-clamp recordings of $I_{N a P}$. Hippocampal slices were submerged in a chamber mounted to the stage of an upright microscope (Axioskop FS, Zeiss) and superfused with solution containing the following (in $\mathrm{mm}$ ): $50 \mathrm{NaCl}, 90$ tetraethylammonium-Cl, 10 HEPES, 3.5 $\mathrm{KCl}, 2 \mathrm{CaCl}_{2}, 2 \mathrm{MgCl}_{2}, 0.2 \mathrm{CdCl}_{2}, 44$-aminopyridine, and 25 D-glucose. Osmolality was adjusted to $305 \mathrm{mOsm} / \mathrm{kg}$ with sucrose and $\mathrm{pH}$ to 7.4 with $\mathrm{NaOH}$. Voltage-clamp recordings were conducted at $20^{\circ} \mathrm{C}$ except for one experiment aiming to compare recordings at $20^{\circ} \mathrm{C}$ and $32^{\circ} \mathrm{C}$ (Fig. $1 D)$. Individual neurons were visualized with infrared differential interference contrast optics. Patch pipettes with a resistance of 3-5 $\mathrm{M} \Omega$ were pulled from borosilicate glass capillaries (outer diameter: $1.5 \mathrm{~mm}$; inner diameter: $0.86 \mathrm{~mm}$; Science Products) on a vertical puller (PP830 ,Narishige) and filled with intracellular solution containing the following (in mM): $110 \mathrm{CsF}, 10$ HEPES-Na, 11 EGTA, $2 \mathrm{MgCl}_{2}, 0.5$ guanosine 5 '-triphosphate 2-amino-2-(hydroxymethyl)-1,3-propanediol (Tris) salt, and 2 adenosine $5^{\prime}$-triphosphate (ATP) $\mathrm{Na}_{2}$ salt. Osmolality was adjusted to $290 \mathrm{mOsm} / \mathrm{kg}$ with sucrose and $\mathrm{pH}$ to 7.25 with $\mathrm{CsOH}$. For some experiments, $1 \mathrm{~mm}$ spermine was included in the intracellular solution. Tight seal $(>1 \mathrm{G} \Omega$ ) whole-cell recordings were obtained using an Axopatch 200B amplifier (Molecular Devices). Series resistance was $6 \pm 2 \mathrm{M} \Omega$. To improve voltage control, the prediction and compensation dials of the amplifier's series resistance compensation were set between $70 \%$ and $90 \%$ to achieve a maximal residual voltage error $<0.5 \mathrm{mV}$ for recordings of $I_{\mathrm{NaP}}$. Currents were recorded with the pClamp9.2 acquisition software (Molecular Devices), sampled at $20 \mathrm{kHz}$, and filtered at $1 \mathrm{kHz}$. All recordings were corrected for a liquid junction potential of $10 \mathrm{mV}$.

Electrophysiology: focal tetrodotoxin applications. Recordings of $I_{\mathrm{NaP}}$ were performed in intact neurons in the slice preparation with the intracellular solution as mentioned above, except for the additional inclusion of $0.1 \mathrm{~mm}$ Alexa-488. The bath solution consisted of the following (in $\mathrm{mm}$ ): $90 \mathrm{NaCl}, 50$ tetraethylammonium-Cl, 10 HEPES, $3.5 \mathrm{KCl}, 3 \mathrm{CsCl}, 2$ $\mathrm{CaCl}_{2}, 2 \mathrm{MgCl}_{2}, 0.2 \mathrm{CdCl}_{2}, 4$-aminopyridine, and 25 D-glucose. Osmolality was adjusted to $305 \mathrm{mOsm}$ with sucrose and $\mathrm{pH}$ to 7.4 with $\mathrm{NaOH}$. Recordings were corrected for a liquid junction potential of $10 \mathrm{mV}$. Focal applications of $1 \mu \mathrm{M}$ TTX in bath solution containing $0.1 \mathrm{~mm}$ Alexa-594 were delivered using a patch pipette connected to a Picospritzer (General Valve). The pressure of the focal application was adjusted under visual control to generate a $20-\mu \mathrm{m}$-sized fluorescent sphere with a $20 \mathrm{~ms}$ pulse. The application pipette was positioned next to the base of the apical dendrite pointing toward stratum radiatum, and a focal TTX puff was applied after 3 or 4 baseline recordings.

Analysis of voltage-clamp recordings. $I_{\mathrm{NaP}}$ was examined using voltage ramp commands. To determine the voltage-dependent activation of $I_{\mathrm{NaP}}$, the TTX-subtracted current responses to voltage ramps were converted to conductance using the following:

$$
G_{(V)}=I_{(V)} /\left(V-V_{\mathrm{Na}}\right)
$$

where $V_{\mathrm{Na}}$ is the $\mathrm{Na}^{+}$equilibrium potential and $V$ the membrane voltage. The voltage-conductance relation was subsequently fitted using the following:

$$
G_{(V)}=G_{\max } /\left(1+\exp \left(\left(V_{50}-V\right) / k_{m}\right)\right)
$$

where $G_{\max }$ is the maximal $\mathrm{Na}^{+}$conductance, $V_{50}$ is membrane potential at which $G_{(V)}$ is half of $G_{\max }$, and $k_{m}$ is the slope at $V_{50}$. In all cases, fitting was done using a Levenberg-Marquardt algorithm.

Electrophysiology: current-clamp recordings. Hippocampal slices were submerged in a chamber mounted to the stage of an upright microscope 
(BX51, Olympus) and superfused with solution containing the following (in mM): $125 \mathrm{NaCl}, 3.5 \mathrm{KCl}, 1.25 \mathrm{NaH}_{2} \mathrm{PO}_{4}, 1.3 \mathrm{MgCl}_{2}, 2.6 \mathrm{CaCl}_{2}, 26$ $\mathrm{NaHCO}_{3}$, and 15 D-glucose ( $\mathrm{pH} 7.4$ when saturated with $95 \% \mathrm{O}_{2} / 5 \%$ $\mathrm{CO}_{2}, 305 \mathrm{mOsmol} / \mathrm{kg}$ ). Current-clamp recordings were conducted at $32^{\circ} \mathrm{C}$. Individual neurons were visualized with infrared differential interference contrast optics. Patch pipettes with a resistance of 3-5 $\mathrm{m} \Omega$ were pulled from borosilicate glass capillaries (outer diameter: $1.5 \mathrm{~mm}$; inner diameter: $0.86 \mathrm{~mm}$; Science Products) on a Flaming/Brown type micropipette puller (P-97, Sutter Instruments) and filled with intracellular solution containing the following (in $\mathrm{mm}$ ): $130 \mathrm{~K}$-gluconate, $20 \mathrm{KCl}, 10$ HEPES, 0.16 EGTA, 2 ATP-Mg, 2 ATP- $\mathrm{Na}_{2}$, and 15 glucose. Osmolality was adjusted to $290 \mathrm{mOsm}$ with sucrose and $\mathrm{pH}$ to 7.2 with $\mathrm{KOH}$. For some experiments, $1 \mathrm{~mm}$ spermine was included in the intracellular solution. Tight seal $(>1 \mathrm{G} \Omega)$ whole-cell recordings were obtained using a BVC-700A amplifier (Dagan). Voltage signals were recorded in bridge mode with pClamp10 acquisition software (Molecular Devices), sampled at $50 \mathrm{kHz}$, and filtered at $10 \mathrm{kHz}$. All recordings were corrected for a liquid junction potential of $15 \mathrm{mV}$.

Analysis of current-clamp recordings. Brief ( $5 \mathrm{~ms}$ ) depolarizing current injections were used to elicit single action potentials in conjunction with an after-depolarizing potential (ADP). We determined the active component of the ADP by subtracting the voltage deflection elicited by a just subthreshold depolarizing current step, from the voltage waveform following an action potential. The magnitude of the ADP was calculated as the integral of the voltage waveform from the fast afterhyperpolarization to the point at which the membrane potential returned to baseline. The fast AHP was measured as the voltage of maximal repolarization within 2 ms after the action potential and preceding the ADP.

Passive properties were determined at a membrane potential of -75 $\mathrm{mV}$ according to standard protocols using long (200 or $800 \mathrm{~ms}$ ) subthreshold hyperpolarizing and depolarizing current injections. Action potential properties were also determined from long current injections. The first action potential within $10 \mathrm{~ms}$ of the onset of the current injection was selected for the analysis. The action potential threshold was determined using the first peak in the second derivative (Thome et al., 2014). The action potential amplitude was determined as the difference between the threshold and peak voltages. The action potential duration was determined as the duration at the half-maximal amplitude. The maximal firing rate (maximal AP frequency) was determined as the average frequency over a $200 \mathrm{~ms}$ pulse at a current injection that elicited the maximum number of action potentials.

Synthesis of 4-((3-(4-(3-aminopropylamino)butylamino)propylamino)methyl)-7-(diethylamino)-2H-chromen-2-one (Spermine-DEACM). Spermine dihydrate $(2 \mathrm{~g}, 8.39 \mathrm{mmol})$ was dissolved in absolute $\mathrm{EtOH}(100 \mathrm{ml})$ at room temperature. DEACM-Br (Seven et al., 2014) (139 mg, 0.42 mmol) was added, and the resulting solution was stirred overnight. The solvent was evaporated and the residue purified by preparative HPLC (M\&N Nucleodur $\mathrm{C}_{18}$ Isis, $21 \times 250 \mathrm{~mm}$ ) to obtain the penta-TFA salt as a mixture of two regioisomers (4:1, $404 \mathrm{mg}, 90 \%)$.

Two-photon imaging. Alexa-594 $(100 \mu \mathrm{M})$ and DEACM-spermine (1 $\mathrm{mm}$ ) were excited by two-photon irradiation using a Ti:Sapphire ultrafast pulsed laser (Chameleon Ultra II, Coherent) and a galvanometer-based scanning system (Prairie Technologies) at a wavelength of $810 \mathrm{~nm}$. CA1 neurons filled with both dyes via the patch-clamp pipette were visualized with a water-immersion objective ( $60 \times, 0.9 \mathrm{NA}$, Olympus). Fluorescent emissions were detected via a dichroic mirror (DXC 575). Red Alexa-594 emission was collected at 605/45, and green DEACM-Spermine emission was collected at 525/70. With these filters, red Alexa-594 emission was not detected above noise in the green channel. Immediately upon breakthrough into the whole-cell patch-clamp configuration, cell morphology was determined using Alexa-594 and $z$-stacks of selected cell compartments obtained. $z$-stacks were obtained throughout the recording of the somatodendritic compartment, apical dendrite (20-50 $\mu \mathrm{m}$ from soma), and the axon $(10-20 \mu \mathrm{m}$ from soma). Fluorescent emission of DEACM-spermine was determined from a region of interest placed within the boundaries of the compartment and at the same location at the different time-points. DEACM-spermine emission was normalized to the initial value at each respective compartment.
Table 1. Primers and probes for real-time quantitative RT-PCR

\begin{tabular}{|c|c|c|}
\hline \multirow{2}{*}{$\frac{\text { Gene (protein) }}{\operatorname{Scn} 1 a\left(\mathrm{Na}_{\mathrm{v}} 1.1\right)}$} & \multicolumn{2}{|c|}{ Primers and probes } \\
\hline & f.p. & 5'-AGAAACCCTTGAGCCCGAAG-3' \\
\hline & r.p. & 5'-CACACTGATTTGACAGCACTTGAA-3' \\
\hline & h.p. & FAM-5'-TTGCTTACTGAAGGCTGTGCAGAG-3'-TAMRA \\
\hline \multirow{3}{*}{$\operatorname{Scn} 2 a\left(\mathrm{Na}_{v} 1.2\right)$} & f.p. & 5'-TCGTTGATGTCTCCTTGGTTAGC-3' \\
\hline & r.p. & 5'-GGGACTTGATGGCACCAAGT-3' \\
\hline & h.p. & FAM-5'-AACTGCAAATGCCTTGGGCTATTCGG-3'-TAMRA \\
\hline \multirow[t]{3}{*}{$\operatorname{Scn} 3 a\left(\mathrm{Na}_{\mathrm{v}} 1.3\right)$} & f.p. & 5'-GCCGCTCCGAGCCTTATC-3' \\
\hline & r.p. & 5'-GATGGAGGGAATTGCACCAA-3' \\
\hline & h.p. & FAM-5' -CGCTTTGAAGGCATGAGGGCTATTCGG-3'-TAMRA \\
\hline \multirow[t]{3}{*}{$\operatorname{Scn} 8 a\left(\mathrm{Na}_{\mathrm{v}} 1.6\right)$} & f.p. & 5'-CATCTTTGACTTTGTGGTGGTCAT-3' \\
\hline & r.p. & 5'-CGGATAACTCGGAATAGGGTTG-3' \\
\hline & h.p. & FAM-5' -CCATTGTGGGAATGTTCCTGGCTG-3'-TAMRA \\
\hline \multirow[t]{3}{*}{ Syp (synaptophysin) } & f.p. & $5^{\prime}$-TCAGGACTCAACACCTCAGTGG-3' \\
\hline & r.p. & $5^{\prime}$-AACACGAACCATAAGTTGCCAA-3' \\
\hline & h.p. & FAM-5'-TTTGGCTTCCTGAACCTGGTGCTCTG-3'-TAMRA \\
\hline \multirow[t]{2}{*}{$\operatorname{Scn} 9 a\left(\mathrm{Na}_{\mathrm{v}} 1.7\right)$} & f.p. & 5'-CTTCACTGTGGGTTGGAACA-3' \\
\hline & r.p. & $5^{\prime}$-ACAGGGTAGGGGACACGAA-3' \\
\hline \multirow[t]{2}{*}{$\operatorname{Scn} 3 b\left(\mathrm{Na}_{\mathrm{v}} \beta 3\right)$} & f.p. & 5'-TGCTACAGAAAGGTCTCTAAGGC-3' \\
\hline & r.p. & 5'-GGTACCACAGAGTTCTCCTTGT-3' \\
\hline \multirow[t]{2}{*}{$\operatorname{Scn} 4 b\left(\mathrm{Na}_{\mathrm{v}} \beta 4\right)$} & f.p. & 5'-TCCTGAAGAAGACCCGAGAG-3' \\
\hline & r.p. & 5'-TGGCTTCTCTTCTGCCTTGG-3' \\
\hline
\end{tabular}

f.p., Forward primer; r.p., reverse primer; h.p., hybridization probe.

Two-photon glutamate uncaging. Two-photon glutamate uncaging at apical radial oblique dendrites of CA1 neurons was performed using a microscope equipped with a galvanometer-based scanning system (Prairie Technologies). Extracellular and intracellular solutions were as described for current-clamp recordings. MNI-caged-L-glutamate (15 mM; Biozol) was dissolved in a HEPES-buffered solution (in $\mathrm{mM}$ as follows: $140 \mathrm{NaCl}, 3 \mathrm{KCl}, 1.3 \mathrm{MgCl}_{2}, 2.6 \mathrm{CaCl}_{2}, 20$ D-glucose, and $10 \mathrm{HEPES}, \mathrm{pH}$ 7.4 adjusted with $\mathrm{NaOH}, 305 \mathrm{mOsmol} / \mathrm{kg}$ ) and filled into puff application pipettes $(<1 \mathrm{M} \Omega)$, which were positioned in close proximity to the selected dendrites. We focused on dendritic sections of primary or secondary radial oblique dendrites $30-100 \mu \mathrm{m}$ away from the soma and used an ultrafast Ti:sapphire pulsed laser (Chameleon Ultra, Coherent) tuned to $730 \mathrm{~nm}$ for multiphoton photo-release at 10 preselected dendritic spines located on a single dendritic branch in close vicinity to each other (within $\sim 10 \mu \mathrm{m}$ ). The midpoint of the stimulated dendritic region was assessed using maximum projection images from two-photon stacks, and the $2 \mathrm{D}$ distance was $76.6 \pm 8.5$ and $88.6 \pm 6.1 \mu \mathrm{m}$ from the soma for dendritic sections from sham-control and pilocarpine-treated animals, respectively ( $n=12$ and $n=18$ dendrites). For near-synchronous stimulation at multiple uncaging positions, the laser focus was rapidly moved with $<0.1 \mathrm{~ms}$ delay between selected positions. The laser dwell time for uncaging was $1 \mathrm{~ms}$ per spine. Due to the reduced synchrony, this results in largely linear summation of single spine EPSPs (Losonczy and Magee, 2006; Losonczy et al., 2008; Thome et al., 2014). The experimental procedure involved near-synchronous uncaging at 10 spines to generate uncaging-induced EPSPs (uEPSPs). The contribution of each unitary spine was then recorded by individual uncaging on each spine independently (interval $>600 \mathrm{~ms}$ ). The single-spine uEPSPs were used to calculate the arithmetic sum and compared with the measured uEPSP.

Preparation of $c D N A$ and probes. Total mRNA was obtained from microdissected hippocampal region CAl of rat brain tissue using Dynabeads mRNA Direct Micro Kit (Dynal) according to the manufacturer's protocol (Invitrogen). cDNA was synthesized from purified mRNA by reverse transcription using the RevertAid $\mathrm{H}$ Minus First-strand cDNA Synthesis Kit (Invitrogen) according to the manufacturer's manual. Quantification of rat gene transcripts was performed by quantitative real-time RT-PCR (ABI PRISM 9700HT, Applied Biosystems). For the mRNA quantification of Scn1b, Scn2b, Sat1, Amd1, and Odc1, we used the TaqMan gene expression assays (Sat1 Rn01419247_g1; Amd1 Rn01407917_g1; Odc1 Rn01469805_m1) and corresponding synaptophysin (Rn00561986_m1; Invitrogen) together with the Maxima Probe/ Rox qPCR Master Mix (Thermo Fisher). Sequences of the primers used to determine rat mRNA expression of $\operatorname{Scn} 9 a$ (Nav1.7), Scn3b, and 

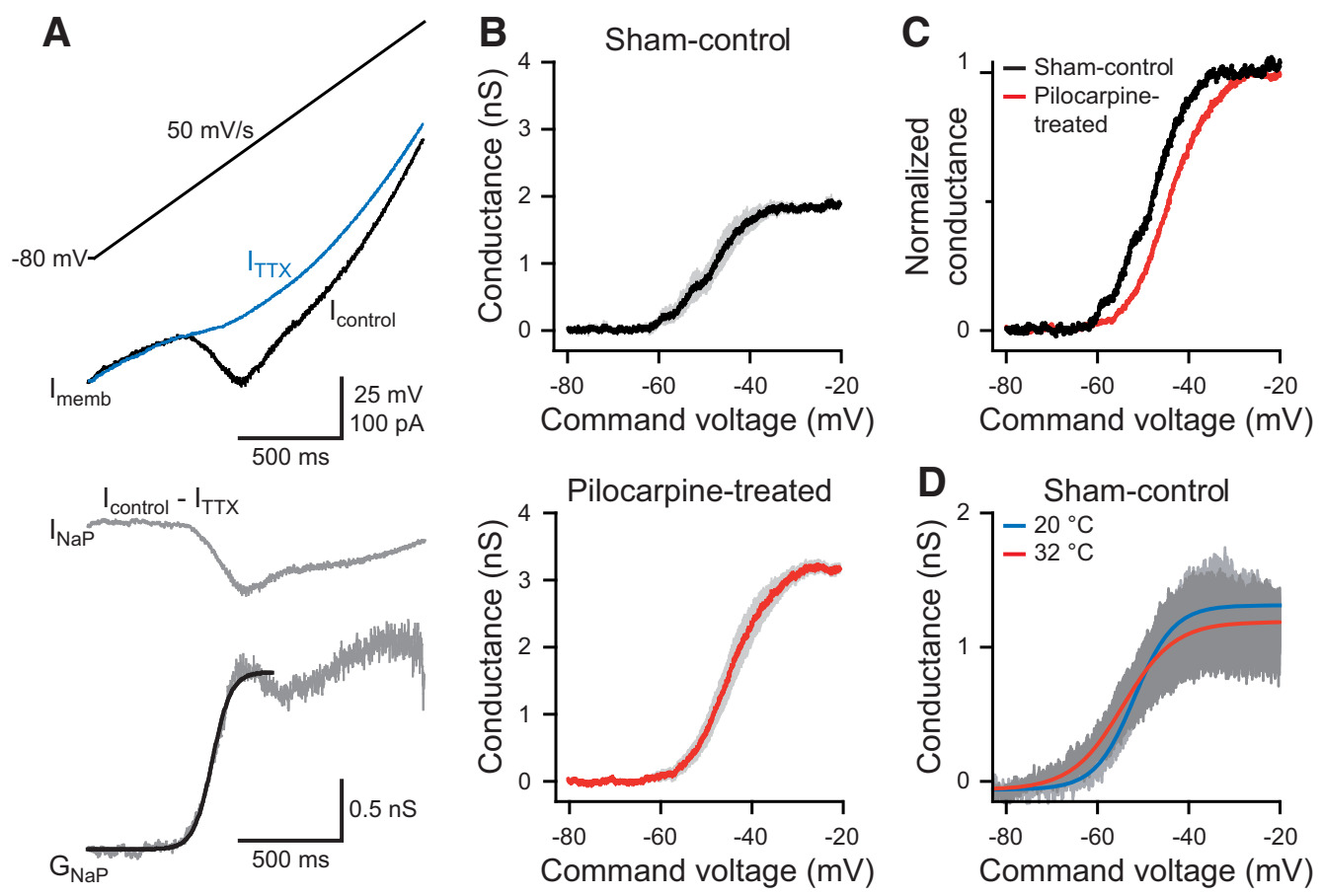

Figure 1. Increased $I_{N a P}$ in CA1 pyramidal neurons from pilocarpine-treated rats. $A$, Isolated $I_{N a P}$ was evaluated in voltage-clamped CA1 pyramidal neurons by applying a slow voltage ramp before $\left(I_{\text {control, }}\right.$, black) and after application of TTX $\left(I_{T T X}\right.$, blue; top traces). The recorded traces were then subtracted from each other $\left(I_{\text {control }}-I_{T T X}\right.$, gray), and the resulting TTX-sensitive current $\left(I_{N a P}\right)$ was mathematically converted to conductance $\left(G_{\text {NaP }}\right)$. By fitting a Boltzmann function to the $G / V$ plot, $G_{\text {max }}$ was determined for every neuron. $B, A$ verage $G / V$ plots $(n=14$ for sham-control, $n=15$ for pilocarpine-treated ; $S E M$ depicted in gray) illustrate the increase of $I_{N a p}$ in $C A 1$ pyramidal neurons from pilocarpine-treated rats. $C$, Average $G / V$ plots of the same neurons, normalized to $G$ max , reveal a slight but significant shift in the voltage of half-maximal activation in pilocarpine-treated compared with sham-control rats ( $p=0.014$, unpaired $t$ test with Welch's correction). Presentation of SEM was omitted for clarity. D, Average $G / V$ plots of CA 1 neurons recorded at different temperature $\left(20^{\circ} \mathrm{C}\right.$ and $32^{\circ} \mathrm{C}, n=5$ for each temperature $)$ show no difference in $G_{\text {max }}$ and $V_{50}(p=0.72$ and 0.52 , respectively, Student's $t$ test $)$ and a significant steeper slope at $20^{\circ} \mathrm{C}(p=0.02$, Student's $t$ test $)$.

Scn $4 b$ were designed with Primer3Plus software (www.bioinformatics. $\mathrm{nl} /$ cgi-bin/primer3plus/primer3plus.cgi; Table 1) and used together with SYBR Green Kit (Thermo Fisher). Sequences of the primers and probes used to determine rat mRNA expression of Scn1a $\left(\mathrm{Na}_{\mathrm{V}} 1.1\right)$, Scn2a $\left(\mathrm{Na}_{\mathrm{V}} 1.2\right), \operatorname{Scn} 3 a\left(\mathrm{Na}_{\mathrm{V}} 1.3\right), \operatorname{Scn} 8 a\left(\mathrm{Na}_{\mathrm{V}} 1.6\right)$, and synaptophysin were designed with Primer Express software (Invitrogen; Table 1). No significant homology of the amplicon sequences with other previously described genes has been found searching GenBank databases by BLASTN program (http://blast.ncbi.nlm.nih.gov/Blast.cgi). Real-time RT-PCR for SYBR Green was performed in a $6.25 \mu \mathrm{l}$ reaction volume containing $3.125 \mu \mathrm{l}$ of Master Mix, $0.1875 \mu \mathrm{l}$ of forward and reverse primers (10 $\mu \mathrm{M}$ each), 1.5 $\mu \mathrm{l}$ of DEPC- $\mathrm{H}_{2} \mathrm{O}$, and cDNA dissolved in $1.25 \mu \mathrm{l}$ of DEPC- $\mathrm{H}_{2} \mathrm{O}$. For the SYBR Green Assay, we used the following PCR protocol: After preincubation for $2 \mathrm{~min}$ at $50^{\circ} \mathrm{C}$ and $10 \mathrm{~min}$ at $95^{\circ} \mathrm{C}$, we performed 40 PCR cycles (20 s at $95^{\circ} \mathrm{C}$ followed by $30 \mathrm{~s}$ at $60^{\circ} \mathrm{C}$ and $40 \mathrm{~s}$ at $72^{\circ} \mathrm{C}$ ). The SYBR Green fluorescence signal was measured in each cycle. For the probe assays, we used a $6.25 \mu \mathrm{l}$ reaction volume containing $3 \mu \mathrm{l}$ of Master Mix, $0.3 \mu \mathrm{l}$ of TaqMan gene expression assay, or $0.1875 \mu \mathrm{l}$ forward and reverse primers, and $0.0625 \mu \mathrm{l}$ probe (10 $\mu \mathrm{M}$ each), respectively, $1.7 \mu \mathrm{l}$ of DEPC $-\mathrm{H}_{2} \mathrm{O}$, and cDNA dissolved in $1.25 \mu \mathrm{l}$ of DEPC- $\mathrm{H}_{2} \mathrm{O}$. Cycling conditions of the probe assays were $50^{\circ} \mathrm{C}(2 \mathrm{~min}), 94^{\circ} \mathrm{C}(10 \mathrm{~min})$, followed by a two-step PCR with 40 cycles of $94^{\circ} \mathrm{C}(15 \mathrm{~s})$ and $59^{\circ} \mathrm{C}(60 \mathrm{~s})$. Reactions were performed at least in triplets. Transcript quantification was performed as relative gene expression according to the $\Delta \Delta \mathrm{C}_{\mathrm{t}}$ method (Fink et al., 1998) compared with the neuron-specific reference gene, as it lacks significant expression changes following pilocarpine-induced SE (Chen et al., 2001). The signal threshold was set within the exponential phase of the reaction for determination of the threshold cycle $\left(\mathrm{C}_{\mathrm{t}}\right)$.

Measurement of polyamines by HPLC. For the polyamine assay, the brain tissue was treated with $3 \times$ volume $4 \%$ perchloric acid and sonicated $(40 \mathrm{~W}, 60 \mathrm{~s})$ on ice, followed by extraction of polyamines overnight at $4^{\circ} \mathrm{C}$. After centrifugation at $10,000 \times g$ for $20 \mathrm{~min}, 100 \mu \mathrm{l}$ of the supernatants was mixed with $300 \mu \mathrm{l}$ of $2 \mathrm{~N} \mathrm{NaOH}$ and $3 \mu l$ of benzoyl chloride. After incubation for $20 \mathrm{~min}$ at $23^{\circ} \mathrm{C}$, the reaction was stopped by the addition of $500 \mu \mathrm{l}$ of a saturated $\mathrm{NaCl}$ solution. Polyamines were extracted in $500 \mu \mathrm{l}$ chloroform. After centrifugation at $10,000 \times g$ for $10-20 \mathrm{~min}$, the chloroform layer was collected, evaporated to dryness, and redissolved in $100 \mu \mathrm{l} 55 \%$ methanol. Polyamine levels were detected on a Smartline Series HPLC system (Knauer). For this purpose, $20 \mathrm{ml}$ aliquots were injected onto a $250 \times 2 \mathrm{~mm}$ Eurospher 100-3 C18 column with precolumn (Knauer). Polyamine separation was done as previously described (Ditzen et al., 2010).

Data analyses. All data are presented as mean \pm SEM. All data analyses were done with Clampfit 9.2 software (Molecular Devices), IGOR Pro (Wavemetrics), GraphPad Prism (GraphPad Software), and Excel (Microsoft). Statistical tests used are mentioned throughout this manuscript.

\section{Results}

\section{Upregulation of $I_{\mathrm{NaP}}$ in CA1 pyramidal neurons from} pilocarpine-treated rats

We first examined the magnitude of $I_{\mathrm{NaP}}$ in CA1 pyramidal neurons from sham-control and pilocarpine-treated rats. Slow voltage ramps elicited pronounced inward currents that were sensitive to TTX and thus correspond to $I_{\mathrm{NaP}}$ (Fig. 1A). Subtracting traces in the presence of $500 \mathrm{~nm}$ TTX from those obtained in ACSF enabled us to isolate $I_{\mathrm{NaP}}$. (Fig. $1 \mathrm{~A}, I_{\text {control }^{-}}$ $I_{\mathrm{TTX}}$, gray). This current was strongly upregulated by $70 \%$ in pilocarpine-treated compared with sham-control rats (from $1.97 \pm 0.31 \mathrm{nS}$ to $3.36 \pm 0.5 \mathrm{nS}, n=14$ and $n=15 ; p=0.026$, unpaired $t$ test with Welch's correction; Fig. $1 B$ ), as described previously (Chen et al., 2011). To reveal shifts in voltage dependence, the relations depicted in Figure $1 B$ were normalized to the maximal $I_{\mathrm{NaP}}$ conductance. This disclosed a slight but significant rightward shift in the voltage of half-maximal activation in pilocarpine-treated compared with sham-control rats $(-42.6 \pm 1.7 \mathrm{mV}$ and $-47.9 \pm 1.0 \mathrm{mV}, n=15$ and $n=14$, 
A pore-forming subunits
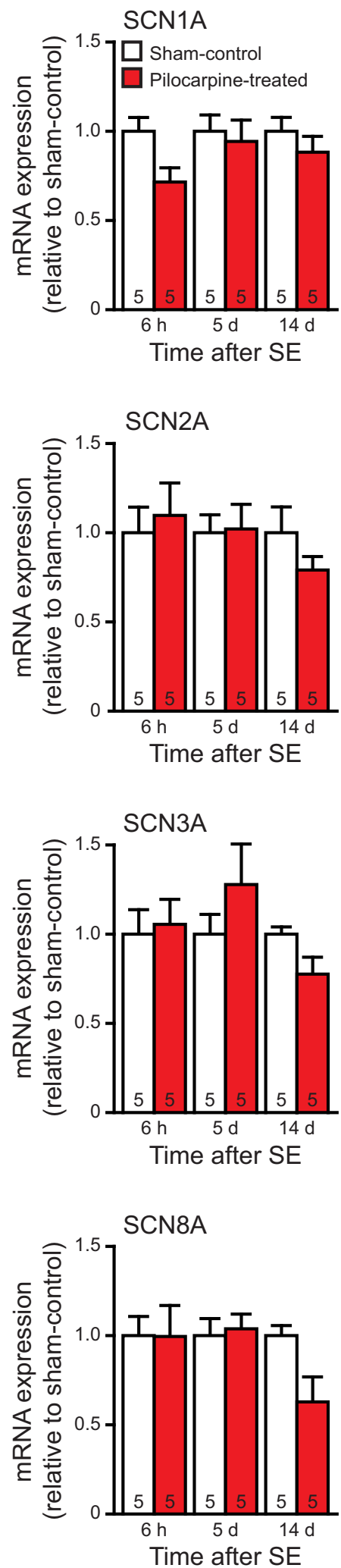

B
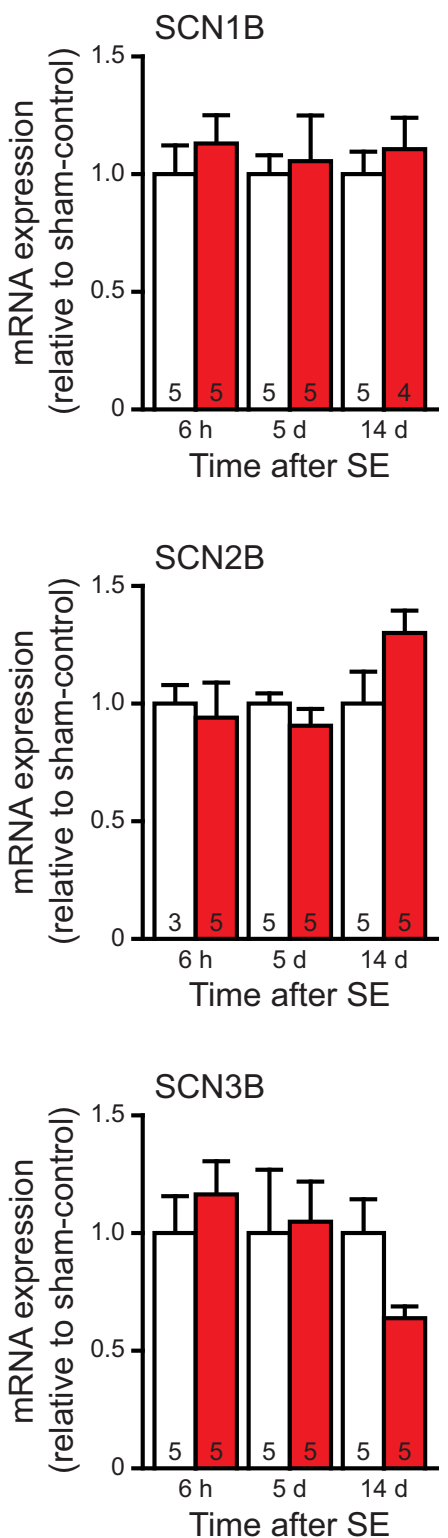

respectively; $p=0.014$, unpaired $t$ test with Welch's correction; Fig. 1C). In a separate set of experiments we examined if $I_{\mathrm{NaP}}$ changes with recording temperature. We did not find a significant difference in $G_{\max }$ for recordings at $20^{\circ} \mathrm{C}$ and $32^{\circ} \mathrm{C}$ (the temperature for voltageclamp and current-clamp recordings, respectively; $p=0.72$, Student's $t$ test).

Lack of regulation of $\mathrm{Na}^{+}$channel subunits on the mRNA or protein levels Because numerous changes in specific voltage-gated ionic currents rely on transcriptional changes (Bernard et al., 2004; Jung et al., 2007; Becker et al., 2008), we first measured mRNA abundance of the major CNS $\mathrm{Na}^{+}$channel $\alpha$ subunits $\mathrm{Na}_{\mathrm{V}} 1.1, \mathrm{Na}_{\mathrm{V}} 1.2, \mathrm{Na}_{\mathrm{V}} 1.3$, and $\mathrm{Na}_{\mathrm{V}} 1.6$, as well as the accessory $\beta_{1}, \beta_{2}$, and $\beta_{3}$ subunits, with real-time quantitative RTPCR using mRNA isolated from the CA1 region of sham-control and pilocarpinetreated animals. We were unable to identify any significant changes in mRNA levels encoding for any of the poreforming (Fig. 2A) or accessory subunits (Fig. 2B) tested at any of the three examined time points ( $6 \mathrm{~h}, 5 \mathrm{~d}$, and $14 \mathrm{~d}$ ) after SE (Mann-Whitney $U$ test with a Bonferroni correction of the significance level to $p<0.0071$; Fig. 2A). In addition to the subunits depicted, we also examined the expression of $\mathrm{Na}_{\mathrm{v}} 1.7$ and $\beta_{4}$ subunits. However, the abundance of these transcripts was extremely low in the CA1 subfields, and they were therefore not further quantitatively analyzed. These experiments show that, despite the functional $I_{\mathrm{NaP}}$ upregulation after SE, changes in the expression of $\mathrm{Na}_{\mathrm{v}}$ subunits at the mRNA levels are not present, suggesting that the $I_{\mathrm{NaP}}$ upregulation is mediated by other mechanisms.

\section{Altered polyamine-dependent modulation accounts for $I_{\mathrm{NaP}}$ upregulation}

A powerful modulatory system that regulates $I_{\mathrm{NaP}}$ magnitude is the polyamine system. The endogenous polyamines spermine and spermidine were recently shown to strongly suppress $\mathrm{Na}^{+}$currents (Huang and Moczydlowski, 2001). Thus, loss of this inhibitory action after SE could augment $I_{\mathrm{Nap}}$. We addressed this hypothesis by examining the levels of the

Figure 2. Lack of $\mathrm{Na}_{v}$ channel mRNA upregulation after SE. Graphs represent hippocampal CA1 regional mRNA expression of pore-forming $\alpha$-subunits $(\boldsymbol{A})$ and accessory $\beta$-subunits $(\boldsymbol{B})$ for the indicated $\mathrm{Na}_{\mathrm{v}}$ channels at $6 \mathrm{~h}, 5 \mathrm{~d}$, and $14 \mathrm{~d}$ after SE. The mRNA expression was measured with RT-PCR in CA1 mini-slices from sham-control (white bars) and pilocarpine-treated (red bars) rats in parallel, and normalized to the expression level of synaptophysin of the same sample. For statistical comparison, these values were then normalized to the mean of $\mathrm{Na}_{v}$ mRNA expression in sham-control rats. The number of animals used is noted at the bottom of

\section{$\leftarrow$}

each bar, no statistically significant differences between sham-control and pilocarpine-treated rats were found for any of the tested $\mathrm{Na}_{\mathrm{v}}$ channels (Mann-Whitney $U$ test with a Bonferroni correction of the significance level to $p<0.0071$ ). 

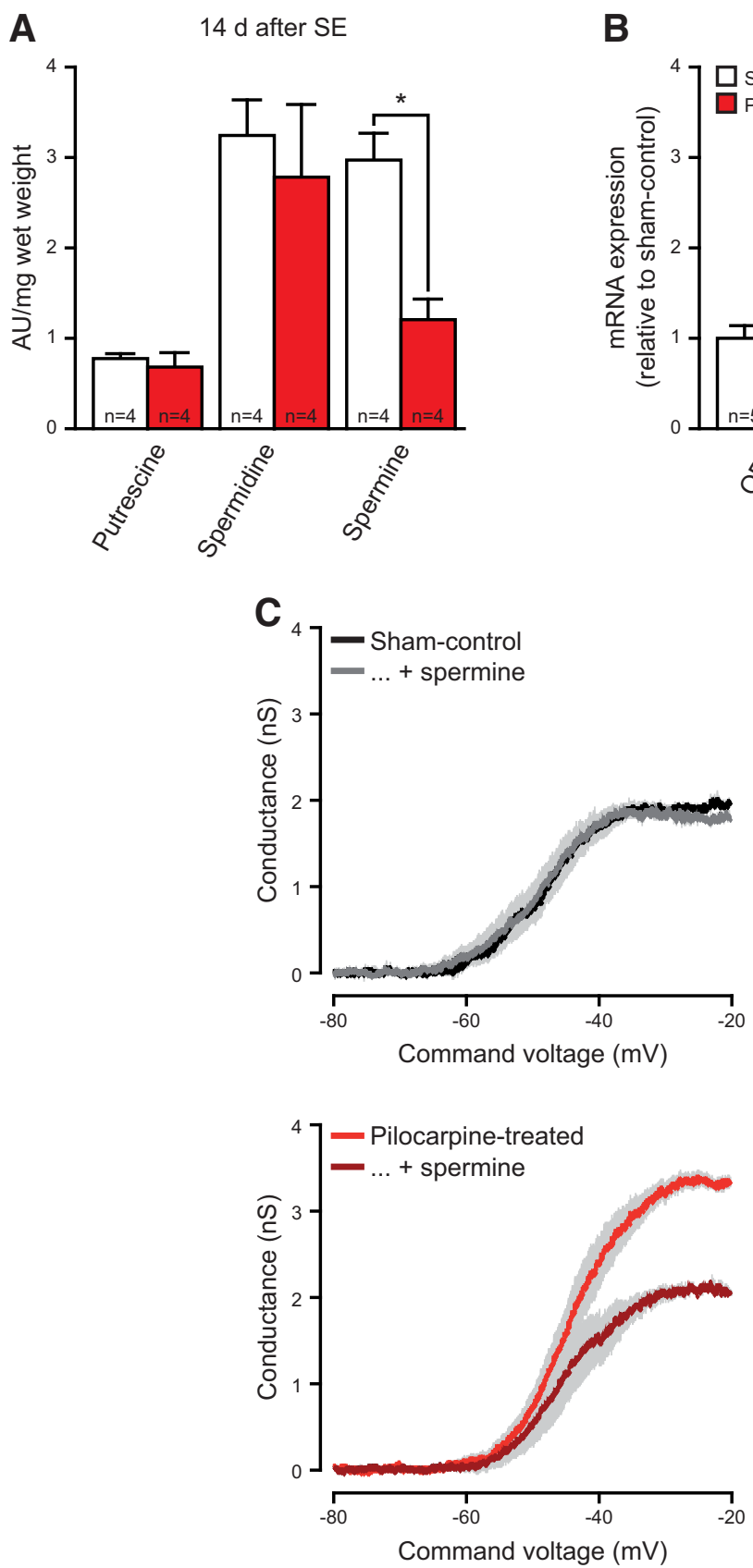

B

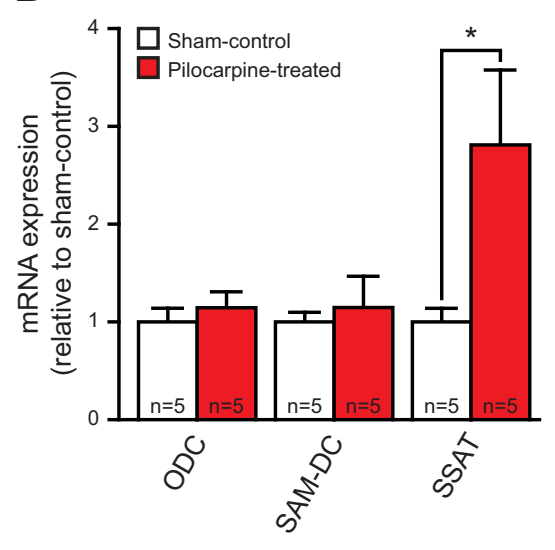

$14 \mathrm{~d}$ after SE

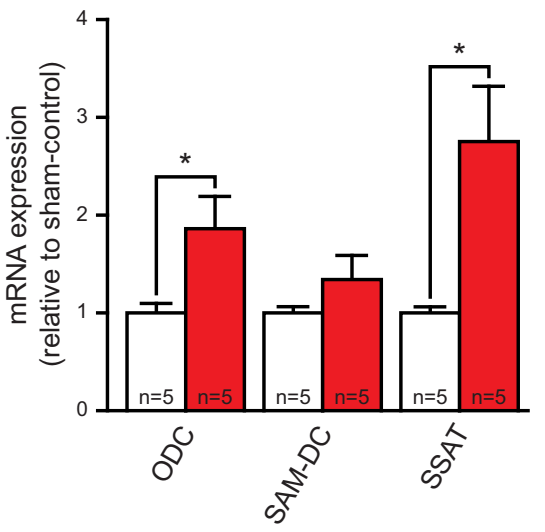

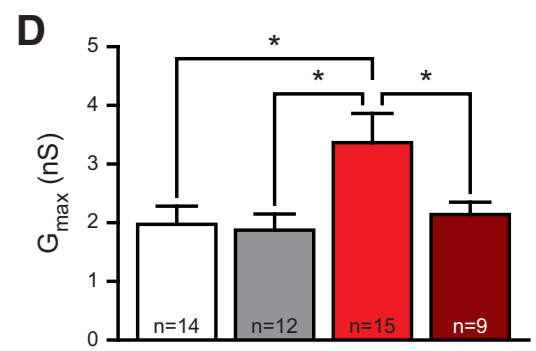
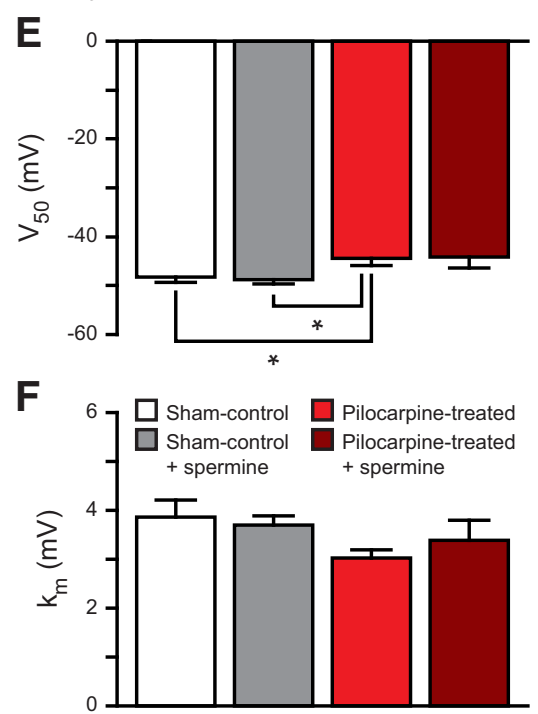

Figure 3. Altered polyamine-dependent modulation accounts for $I_{N a P}$ upregulation. $A$, Hippocampal tissue polyamine levels determined by HPLC with units normalized to wet tissue weight. The amount of putrescine, spermidine, and spermine was measured for sham-control (white bars) and pilocarpine-treated (red bars) rats in parallel. The number of animals used is noted at the bottom of each bar. *Statistically significant difference ( $t$ test with Welch's correction, $p<0.05$ ). $\boldsymbol{B}$, Graphs represent RT-PCR experiments in hippocampal area CA1 for quantitative mRNA expression of enzymes involved in spermine anabolism (ODC, SAMDC) and catabolism (SSAT). The expression of enzymes was measured for sham-control (white bars) and pilocarpine-treated (red bars) rats in parallel, and values were normalized to the mean of expression in sham-controls. The number of animals used is noted at the bottom of each bar. *Statistically significant differences (Mann-Whitney $U$ test, $p<0.05$ ). C, Average $G / V$ plots illustrating the voltage dependence of $I_{N a p}$ in $C A 1$ pyramidal neurons from rats of the specified groups. Note the effect of intracellular spermine $(1 \mathrm{~mm})$ in pilocarpine-treated animals. The numbers of neurons that were included in the average traces equal the ones in $\boldsymbol{D}$. Gray represents SEM. $D-F$, Bar graphs represent $I_{N a P}$ parameters as calculated by fitting a Boltzmann function to single $G / V$ plots. The number of neurons is noted at the bottom of each bar in $\boldsymbol{D}$. ${ }^{*}$ Statistically significant differences ( $p<0.05$ in Newman-Keul's multiple-comparison test following one-way ANOVA).

polyamines putrescine, spermidine, and spermine in brains of sham-control and pilocarpine-treated rats quantitatively using HPLC (Fig. 3A). At $14 \mathrm{~d}$ after SE, when $I_{\mathrm{NaP}}$ was increased, hippocampal spermine levels were significantly reduced by $60 \%(t$ test with Welch's correction, $p=0.0042$ ), whereas the putrescine and spermidine levels were not significantly changed $(p=0.58$ and $p=0.63$, respectively; Fig. $3 A$ ). To address the cellular mechanisms of reduced spermine content, we performed quan- titative real-time RT-PCR analyses of the expression of the spermine synthesizing enzymes ornithine decarboxylase (ODC) and S-adenosylmethionine decarboxylase (SAMDC), as well as the major catabolic enzyme spermidine/spermine $\mathrm{N}(1)$ acetyltransferase (SSAT) in the CA1 subfield 5 and $14 \mathrm{~d}$ after SE. We found a robust upregulation of SSAT at 5 and $14 \mathrm{~d}$ after SE (Fig. 3B; Mann-Whitney $U$ test, $p=0.0079$ and $p=0.0079$ ). A less pronounced upregulation was seen for ODC only at the later 

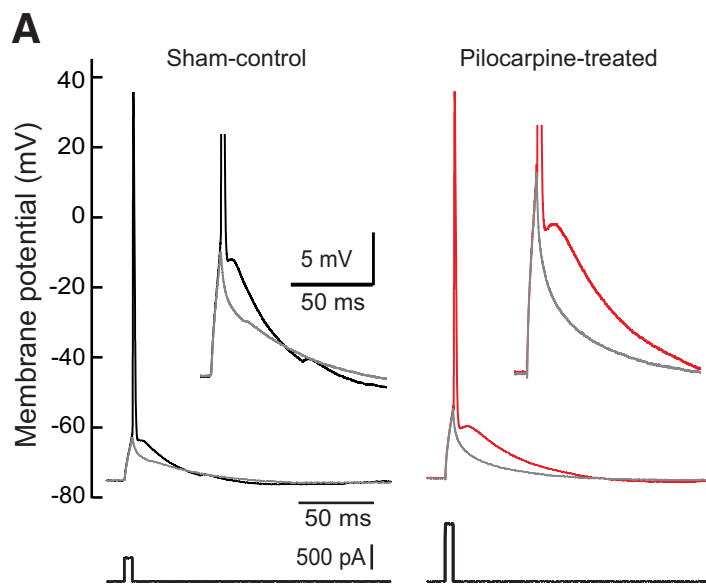

C

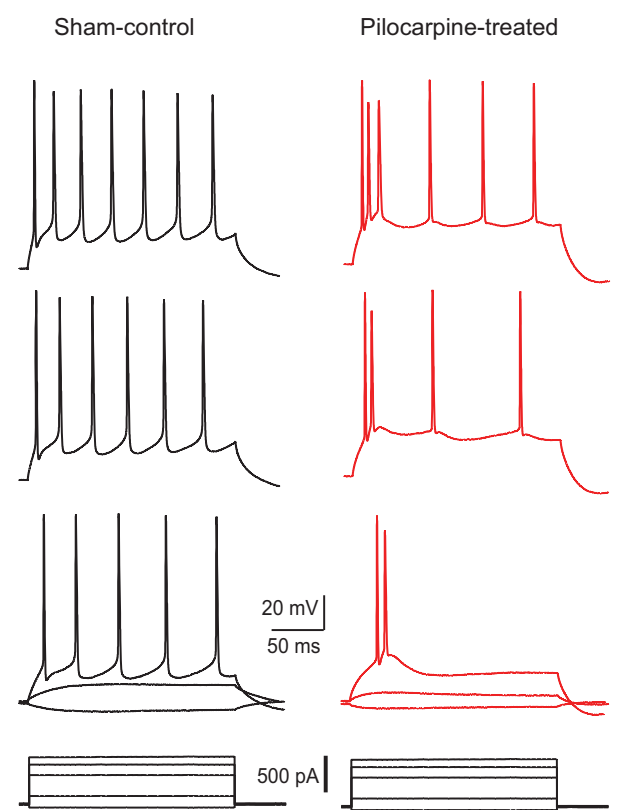

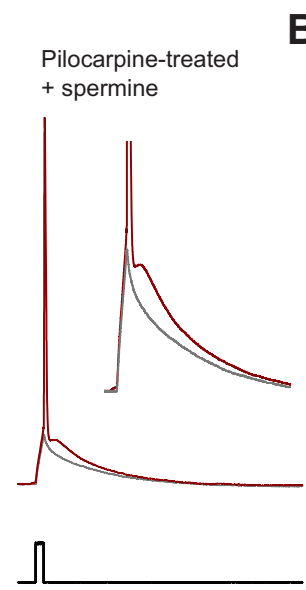
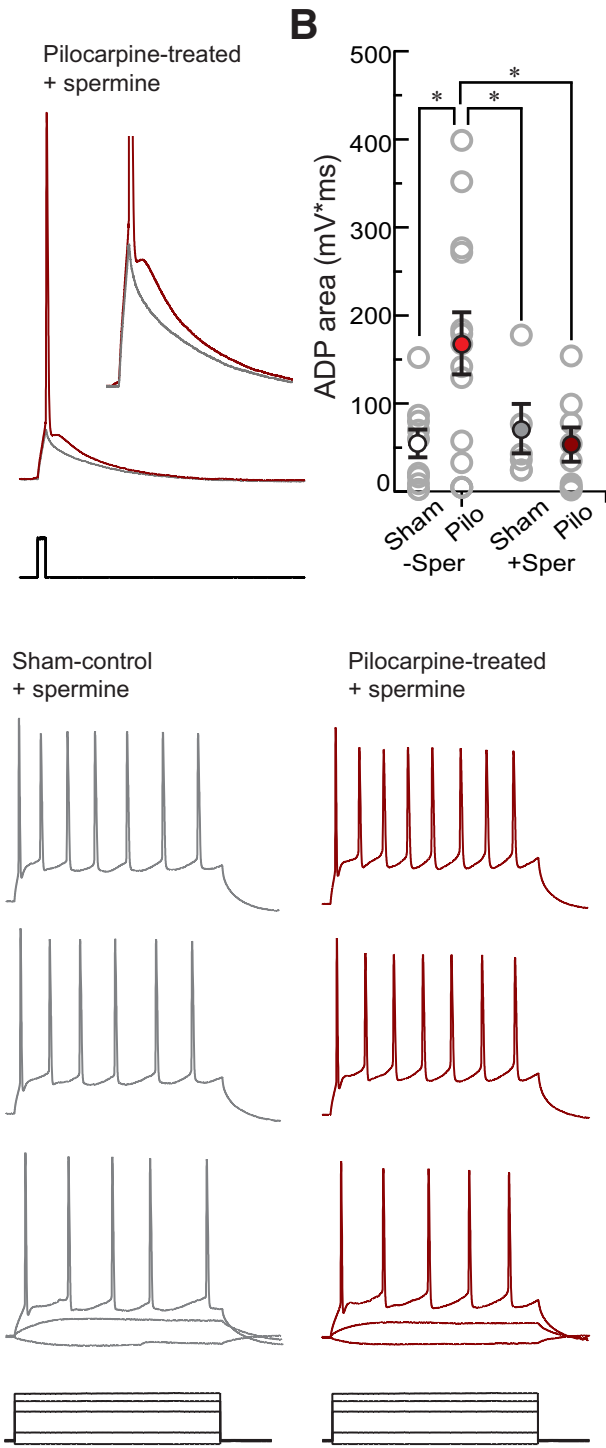

Pilocarpine-treated + spermine
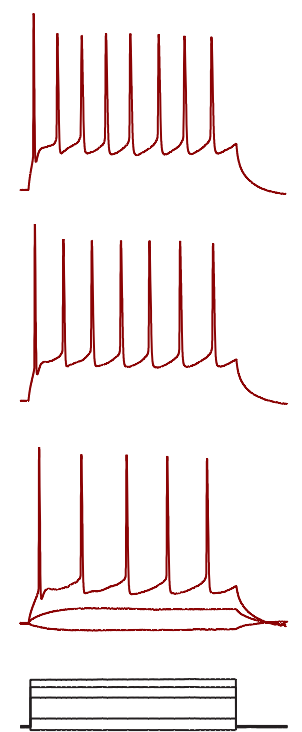

Figure 4. Increased spike ADP in pilocarpine-treated rats is sensitive to spermine. A, Current-clamp recordings from CA1 neurons in hippocampal slices under the indicated conditions. Threshold straddling brief (5 ms) depolarizing current injections (depicted below the voltage traces) were applied via the somatic recording patch pipette. Just subthreshold responses (gray traces) were subtracted from just suprathreshold responses, and the ADP area calculated. Insets, Truncated action potentials for enhanced ADP presentation. B, Summary plot of spike ADP area under the indicated condition. The spike ADP was significantly increased in pilocarpine-treated animals, compared with sham-control animals, and this increase was sensitive to intracellular spermine $\left(F_{(3,36)}=5.27, p=0.0041\right) .{ }^{*} p<0.05$ (one-way ANOVA followed by Newman-Keul's multiple-comparison test). C, Current-clamp recordings from CA1 neurons in hippocampal slices under the indicated conditions. Long ( $200 \mathrm{~ms}$ ) depolarizing current injections (depicted below the voltage traces) were applied via the somatic recording patch pipette. Note the irregular firing pattern of the neuron from a pilocarpine-treated rat, showing doublet action potentials or burst firing at higher depolarization. This bursting behavior was significantly different from the regular firing in the other groups of animals ( $\chi^{2}$ test, $p=0.0046$ ).

time point (Mann-Whitney $U$ test, $p=0.0079$ ), with no significant regulation of SAMDC. Collectively, these results suggest that neuronal spermine levels are reduced, most likely due to a persistent and long-lasting increase in SSAT expression.

We next tested whether a loss of spermine-dependent block accounts for $I_{\mathrm{NaP}}$ upregulation. In this case, supplementing spermine intracellularly should reduce $I_{\mathrm{NaP}}$ in pilocarpinetreated rats more than in sham-control animals. We therefore performed interleaved recordings with either an excess of spermine $(1 \mathrm{~mm})$ present or absent in the patch pipette solution. Spermine did not have any effects on the average $I_{\mathrm{NaP}}$ magnitude in sham-control rats (Fig. $3 C$ for representative examples, Fig. 3D, leftmost bars). In pilocarpine-treated rats, however, the presence of intracellular spermine reduced $I_{\mathrm{NaP}}$ to a magnitude similar to that observed in sham-control ani- mals (Fig. 3C,D; analysis performed with one-way ANOVA, $F_{(3,46)}=3.79, p=0.016$, followed by Newman-Keul's multiple-comparison test, $p<0.05)$. These results demonstrate that excess intracellular spermine completely obviates the SE-induced increase in $I_{\mathrm{NaP}}$. Additionally, there was a difference in the voltage dependence of $I_{\mathrm{NaP}}$. Half-maximal activation of $I_{\mathrm{NaP}}$ was $5-8 \mathrm{mV}$ more depolarized in pilocarpine-treated animals compared with sham-control animals recorded with and without intracellular spermine $\left(F_{(3,46)}=4.82, p=0.0053\right.$, one-way ANOVA followed by Newman-Keul's multiple-comparison test with $p<0.05$; Fig. $3 E)$, suggesting that this alteration is not due to reduced spermine levels. The slope of the activation curve, however, was the same for all groups of neurons $\left(F_{(3,46)}=1.38, p=\right.$ 0.2617, one-way ANOVA; Fig. $3 F$ ). 


\begin{tabular}{|c|c|c|c|c|}
\hline & \multicolumn{4}{|l|}{ Experimental condition } \\
\hline & \multicolumn{2}{|l|}{ No spermine } & \multicolumn{2}{|l|}{1 mm spermine } \\
\hline & sham-control $(n=9)$ & Pilocarpine-treated $(n=10)$ & sham-control $(n=5)$ & Pilocarpine-treated $(n=8)$ \\
\hline \multicolumn{5}{|l|}{ Passive properties } \\
\hline Resting membrane potential (mV) & $-75 \pm 1$ & $-72 \pm 1$ & $-72 \pm 1$ & $-72 \pm 1$ \\
\hline Membrane resistance $(\mathrm{M} \Omega)$ & $113 \pm 8$ & $88 \pm 11$ & $111 \pm 9$ & $97 \pm 8$ \\
\hline Membrane time constant (ms) & $28 \pm 3$ & $26 \pm 4$ & $28 \pm 4$ & $25 \pm 3$ \\
\hline \multicolumn{5}{|l|}{ Action potential properties } \\
\hline Threshold (mV) & $-56 \pm 1$ & $-52 \pm 1$ & $-54 \pm 1$ & $-54 \pm 1$ \\
\hline Peak amplitude (mV) & $32 \pm 2$ & $29 \pm 1$ & $29 \pm 1$ & $27 \pm 1$ \\
\hline Duration (ms) & $1.14 \pm 0.05$ & $1.12 \pm 0.03$ & $1.08 \pm 0.03$ & $1.06 \pm 0.02$ \\
\hline Fast afterhyperpolarization (mV) & $-49 \pm 1$ & $-46 \pm 1^{*}$ & $-50 \pm 1$ & $-50 \pm 1$ \\
\hline Peak depolarization rate $(\mathrm{V} / \mathrm{s})$ & $322 \pm 15$ & $267 \pm 10^{\#}$ & $324 \pm 20$ & $296 \pm 8$ \\
\hline Peak repolarization rate (V/s) & $77 \pm 3$ & $71 \pm 2$ & $71 \pm 3$ & $73 \pm 2$ \\
\hline $\begin{array}{l}\text { Action potential frequency (Hz) at intermediate } \\
\text { current injection (300 pA, } 200 \mathrm{~ms})\end{array}$ & $30.5 \pm 1.3$ & $28.2 \pm 1.8$ & $29.9 \pm 3.1$ & $33.2 \pm 2.9$ \\
\hline Maximal action potential frequency (Hz) & $48 \pm 3$ & $49 \pm 3$ & $46 \pm 5$ & $46 \pm 5$ \\
\hline
\end{tabular}

*Pilocarpine-treated group significantly different from all other groups $\left(F_{(3,31)}=4.78, p=0.0075\right.$, one-way ANOVA followed by Newman-Keul's multiple comparison test with $\left.p<0.05\right)$.

\#Pilocarpine-treated group significantly different from both sham groups $\left(F_{(3,32)}=5.98, p=0.0024\right.$, one-way ANOVA followed by Newman-Keul's multiple comparison test with $\left.p<0.05\right)$.

\section{Increased spike afterdepolarization in pilocarpine-treated rats}

In CA1 pyramidal cells, single action potentials elicited by brief $(5$ ms) depolarizing current pulses were followed by an ADP, which in control rats is mediated primarily by $I_{\mathrm{NaP}}$ (Azouz et al., 1996; Jensen et al., 1996; Su et al., 2002; Yue et al., 2005). In previous studies using sharp microelectrodes, spike ADPs were strongly enlarged in epileptic animals (Sanabria et al., 2001), due both to augmented $I_{\mathrm{NaP}}$ (Chen et al., 2011) and an increase in T-type $\mathrm{Ca}^{2+}$ currents (Su et al., 2002; Becker et al., 2008). This finding was replicated also in the present study using patch pipette recordings (Fig. 4A, quantification in Fig. 4B). We hypothesized that the epilepsy-associated increase in the spike ADP should be reduced by intracellular spermine consequent to the spermine inhibition of $I_{\mathrm{NaP}}$. Indeed, intracellular spermine prevented the ADP increase in epileptic animals, normalizing it to shamcontrol values $\left(F_{(3,36)}=5.27, p=0.0041\right.$, one-way ANOVA followed by Newman-Keul's multiple-comparison test with $p<$ 0.05; Fig. $4 B)$.

The larger ADP in the pilocarpine-treated animals altered their action potential firing pattern from regular firing to burst firing, as previously described in this model using sharp microelectrodes (Sanabria et al., 2001; Su et al., 2002; Becker et al., 2008, Chen et al., 2011). In all CA1 neurons recorded from shamcontrol animals, depolarizing current steps elicited trains of action potentials, which showed spike frequency adaptation (regular-firing neurons; see Fig. 4C). However, 50\% of CA1 neurons recorded from pilocarpine-treated animals generated an initial burst of action potentials (i.e., $\geq 2$ action potentials riding on an underlying depolarizing envelope; 5 of 10 compared with 0 of 9 burst-firing neurons in pilocarpine-treated and sham-control animals, respectively; see Fig. 4C). Moreover, the increase in bursting behavior was not present in either control or pilocarpine-treated animals if recordings were performed in the presence of exogenous spermine added to the intracellular solution ( 0 of 5 and 0 of 8 neurons, respectively; see Fig. $4 C$ ). Statistical analysis revealed that these differences were significant ( $\chi^{2}$ test, $\left.p=0.0046\right)$.

We also examined additional passive and active membrane properties. Most passive and active properties were not significantly affected by either the presence of spermine or the induction of chronic epilepsy (one-way ANOVA followed by Newman-Keul's multiplecomparison test with $p<0.05$; Table 2).
Upregulation of $I_{\mathrm{NaP}}$ in proximal apical dendrites

So far, it is unclear which neuronal compartment is primarily affected by $I_{\mathrm{NaP}}$ upregulation. In control CA1 neurons, the density of $I_{\mathrm{NaP}}$ is low in dendrites but high at the axon initial segment in control animals (Andreasen and Lambert, 1999; Yue et al., 2005). Because increased expression of $I_{\mathrm{NaP}}$ at dendritic locations might profoundly affect synaptic integration, we attempted to quantify the magnitude of dendritic $I_{\mathrm{NaP}}$. The experimental setup is shown in Figure 5A. Ramp depolarization evoked whole-cell $I_{\mathrm{NaP}}$, and TTX was pressure-applied via a puffer pipette positioned near the proximal apical dendrite of the patched neuron (see Materials and Methods). Subsequently, TTX was bathapplied to block all cellular $I_{\mathrm{NaP}}$ of the neuron. In sham-control rats, local dendritic applications of TTX did not appreciably reduce $I_{\mathrm{NaP}}$ (Fig. $5 B$, left). Surprisingly, in pilocarpine-treated animals, TTX locally applied to the proximal apical dendrites considerably reduced $I_{\mathrm{NaP}}$ (Fig. $5 B$, middle). This effect was not detectable when spermine was added to the pipette solution (Fig. $5 B$, right). Together, we found a significantly larger dendritic $I_{\mathrm{NaP}}$ component in CA1 pyramidal cells from pilocarpine-treated animals recorded in the absence of spermine compared with all other groups of recorded neurons $\left(F_{(2,31)}=4.15, p=0.0253\right.$, one-way ANOVA followed by Newman-Keul's multiplecomparison test with $p<0.05$; Fig. $5 C$ ). Quantitatively, this component could account for the augmented whole-cell $I_{\mathrm{NaP}}$ in CA1 pyramidal cells from pilocarpine-treated rats. We note, however, that the spatial resolution of this method is low and that we cannot exclude some contribution of somatic $I_{\mathrm{NaP}}$ to this effect. Nevertheless, these experiments suggest that $I_{\mathrm{NaP}}$ upregulation following pilocarpine treatment is largely due to the de novo appearance of $I_{\mathrm{NaP}}$ at the proximal apical dendrites.

\section{Spatial distribution of spermine in neurons}

If the increased $I_{\mathrm{NaP}}$ is due to a decrease in intracellular spermine in epileptic animals, why is the increase in $I_{\mathrm{NaP}}$ localized to dendrites? Two hypotheses can be advanced to explain this finding. First, the spermine decrease might be local due to increased degradation localized within the dendritic compartment. Second, the spermine decrease might be global, but the spermine sensitivity of dendritic versus other persistent $\mathrm{Na}^{+}$channels might differ. To investigate the speed of equilibration of spermine within the cell, we used a fluorescently labeled spermine deriva- 

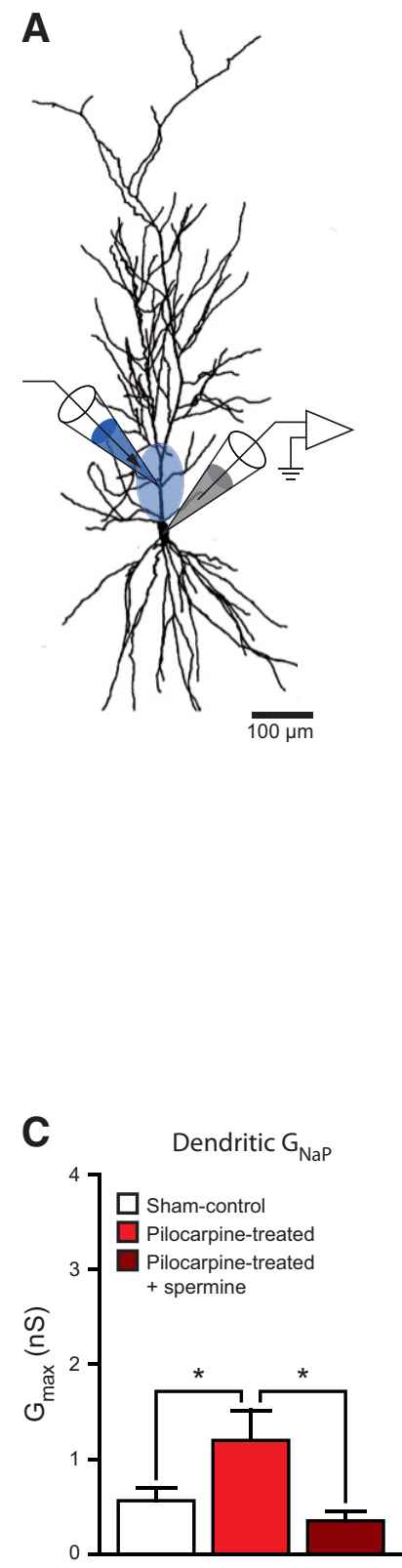
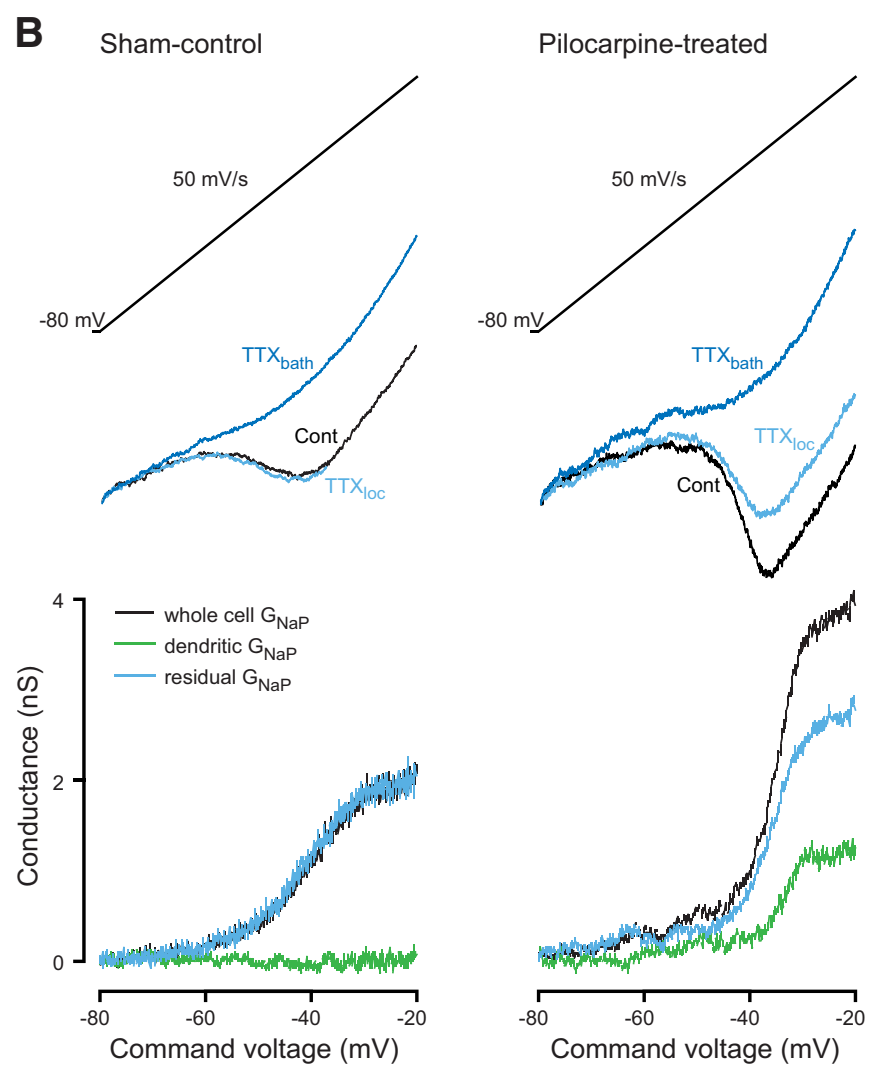
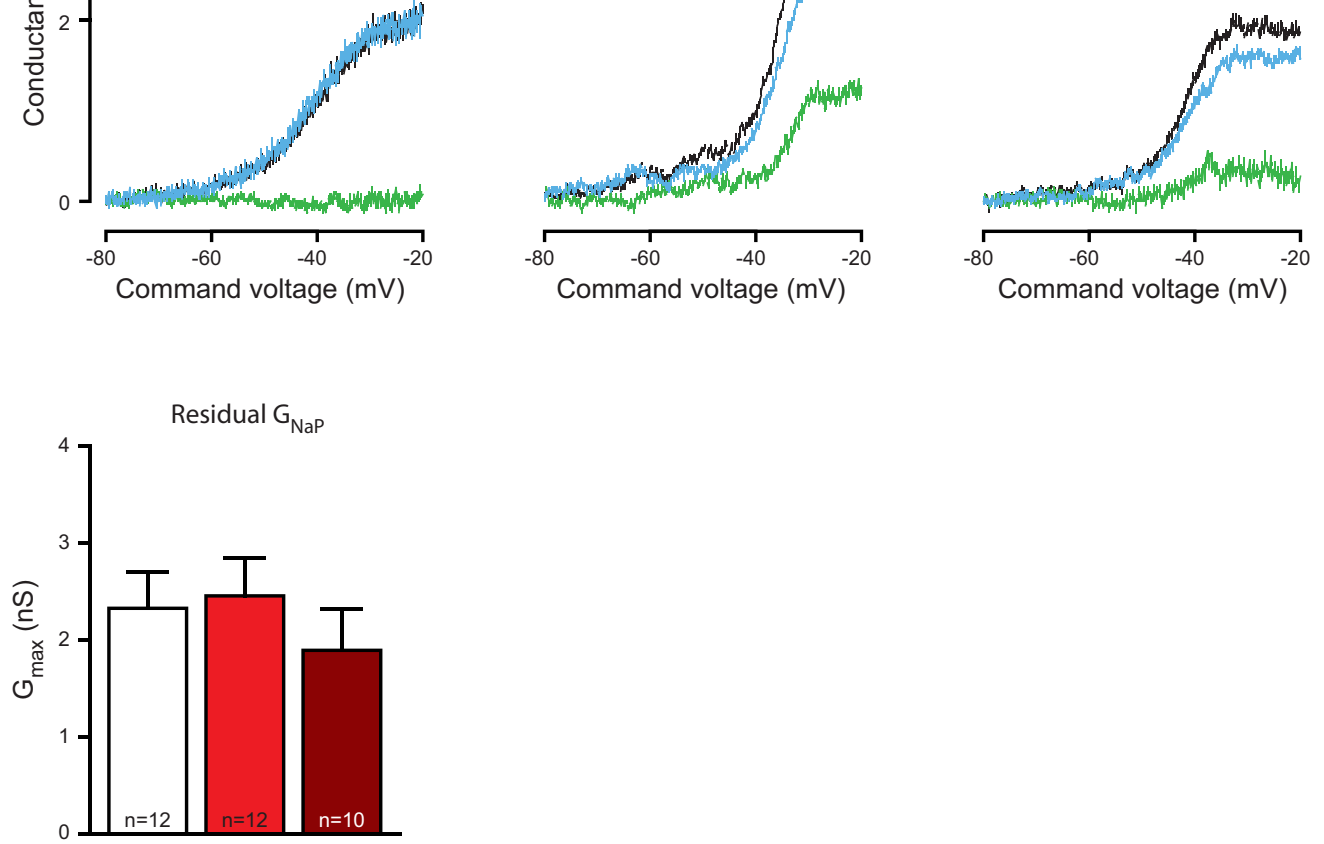

Figure 5. Upregulation and polyamine dependence of $I_{N a P}$ in proximal dendrites. $A$, Diagram of the experimental setup. After achieving stable recording of $I_{\text {NaP }}$ via a somatic patch pipette (gray), TTX (1 $\mu \mathrm{m})$ was focally applied by pressure pulses via a second patch pipette (blue) placed near the proximal dendrite. The flow inside the recording chamber was set to the direction stratum oriens $\rightarrow$ stratum radiatum so that the TTX bolus (light blue) would not reach the axon initial segment or cell soma. $B$, Representative examples of $I_{\text {NaP }}$ recordings (top traces) and the resulting $G / V$ plots (bottom) in CA1 pyramidal neurons from rats of the specified groups. Note the substantial reduction of $I_{\text {NaP }}$ in the cell from a pilocarpine-treated rat by focal TTX application (TTX loc $^{\prime}$ light blue trace). C, Bar graphs represent $I_{N a P}$ parameters as calculated by fitting a Boltzmann function to single $G / V$ plots. The number of neurons is noted at the bottom of each bar in the right graph. *Statistically significant differences ( $p<0.05$, Newman-Keul's multiple-comparison test following one-way ANOVA).

tive. This was synthesized by covalent coupling of spermine and a coumarine-fluorophore (DEACM; Fig. 6A). We then applied DEACM-spermine (1 mM) to CA1 neurons via the patch pipette (Fig. $6 B-D$ ). Fluorescent spermine spread rapidly into both the apical dendrites and axonal compartment within minutes of establishing the whole-cell configuration and remained stable for the duration of the recording ( $25 \mathrm{~min}$; Fig. $6 C, D$ ). These experiments indicate that equilibration of spermine within neurons is rapid, and suggest that even a local upregulation of SSAT is unlikely to create steep concentration gradients between proximal dendrites and axons. Thus, it is more likely that $I_{\mathrm{NaP}}$ in different cellular compartments is differentially regulated by spermine.

\section{Impact of increased proximal dendritic $I_{\mathrm{NaP}}$ on dendritic integration}

In CA1 pyramidal cells, proximal $I_{\mathrm{NaP}}$ can amplify distally generated EPSPs (Andreasen and Lambert, 1999). Therefore, we sought to determine whether $I_{\mathrm{NaP}}$ upregulation due to decreased intracellular spermine in epileptic animals leads to augmented EPSP amplification. To that end, we used two-photon glutamate uncaging onto primary and secondary CA1 apical oblique dendrites to generate uncaging-evoked EPSPs (Fig. 7A). The properties of unitary EPSPs elicited by stimulating individual spines in CA1 neurons from sham-control and pilocarpine-treated rats were similar (see Fig. $7 B-D ; p>0.1$, unpaired Student's $t$ test). 

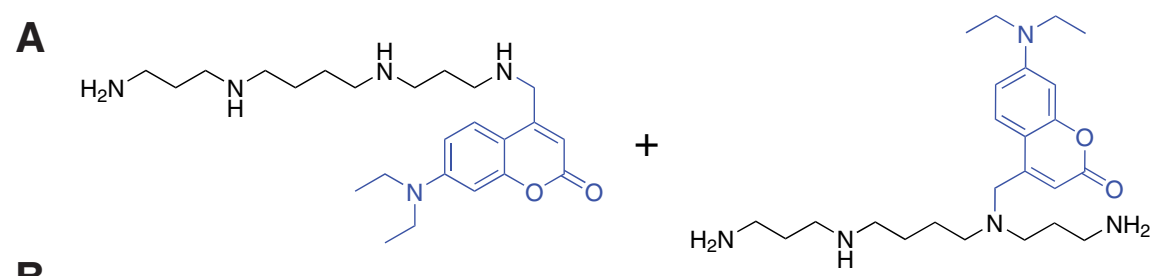

B

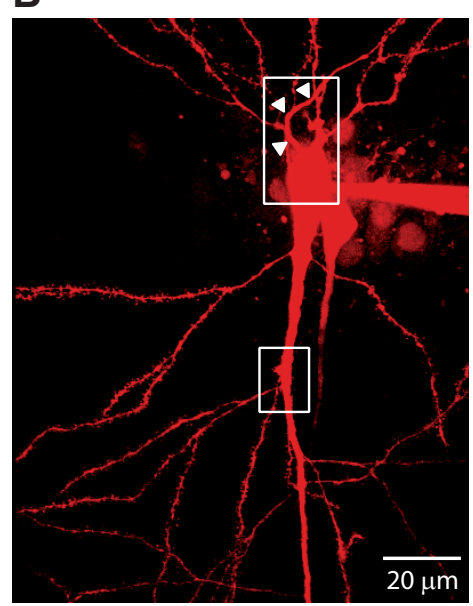

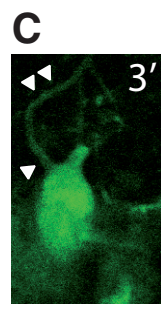
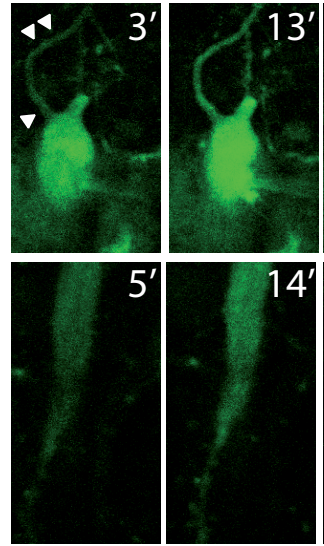
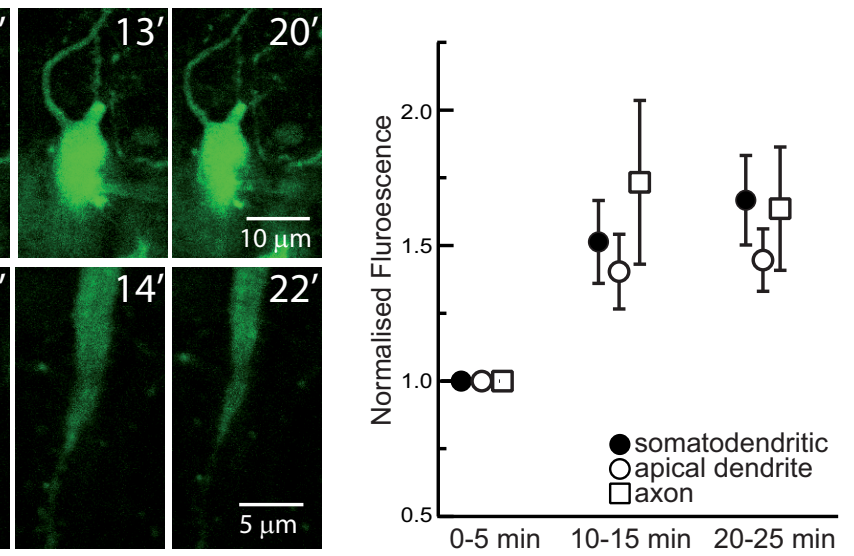

Figure 6. Spread of fluorescently labeled DEACM-spermine throughout CA1 pyramidal neuron. $A$, Structure of DEACM-labeled spermine (mixture of two regioisomers, DEACM moiety labeled in blue.) We then applied DEACM-spermine (1 mM) to CA1 neurons via the patch pipette. $\boldsymbol{B}$, CA1 pyramidal neuron was filled with Alexa-594 (100 $\mu \mathrm{m})$ and DEACM-spermine (1 mM) via the patch pipette. Areas used for analysis are indicated with white boxes (axon marked by arrowheads) in a two-photon image of fluorescent emission from Alexa-594. C, Two-photon fluorescent emission of DEACM-spermine at different time points after cell opening from the areas indicated in $\boldsymbol{B}$. The fluorescent emission increased over time. $\boldsymbol{D}, \mathrm{DEACM}$-spermine fluorescence measured at the indicated time after cell opening, normalized to the emission at the first time-point from a region of interest in the indicated compartments (mean \pm SEM; $n=3$ cells).

Furthermore, applying TTX to block $I_{\mathrm{NaP}}$ did not alter the unitary EPSPs in both groups of neurons recorded with or without spermine in the pipette solution (Fig. $7 C, D ; p>0.1$, paired Student's $t$ test).

In CA1 pyramidal cells from sham-control animals, nearsynchronous glutamate uncaging on multiple spines at proximal apical oblique dendrites elicited compound EPSPs, which were similar in amplitude to the compound EPSP calculated from arithmetically summing each individually evoked unitary EPSP (Fig. 7E). This was evident from plotting the directly measured compound EPSP amplitudes versus those calculated from EPSP summation, which yielded a slope of $0.95 \pm 0.08$ when fitted with a linear line $(n=7$; Fig. $7 F)$. To examine the specific contribution of $\mathrm{Na}^{+}$channels to integration, we examined the effects of applying TTX. Bath-applied TTX failed to significantly affect EPSP summation in these neurons (slope of $0.87 \pm 0.08$ after TTX application, $n=7, p=0.16$, Wilcoxon Signed Rank Test). Thus, in sham-control animals, persistent $\mathrm{Na}^{+}$channels appear to play a negligible role in boosting compound EPSPs generated in proximal dendrites of CA1 pyramidal cells. In contrast, similar analyses performed in neurons from pilocarpine-treated rats yielded a slope $>1(1.08 \pm 0.06, n=9)$, which was significantly reduced by TTX $(0.85 \pm 0.08 ; n=9, p<0.01$, Wilcoxon Signed Rank Test; Fig. $7 E, F)$, thus indicating a boosting of the compound EPSP by the augmented $I_{\mathrm{NaP}}$. This allowed us to calculate the effects of $I_{\mathrm{NaP}}$ on EPSP gain as the difference between the slope values with and without TTX (Fig. 7G). Interleaved experiments with pipette solutions containing spermine allowed us to examine whether the presence of exogenous spermine occludes the changes in TTX-sensitive gain (Fig. 7G). A statistical comparison between all groups revealed that the increased TTX-sensitive component in pilocarpine-treated animals, compared with sham-control animals, was significantly reversed by intracellular spermine (Fig. $7 G ; F_{(3,28)}=4.87, p=0.0075$, one-way ANOVA followed by Newman-Keul's multiple-comparison test with $p<0.05)$.

\section{Discussion}

Our results suggest a novel mechanism of altered dendritic integration in chronic epilepsy. First, our results clearly indicate that epilepsy-associated increases in $I_{\mathrm{NaP}}$ are fully dependent on altered intracellular spermine levels. This notion is supported by the finding that SE-induced increases in $I_{\mathrm{NaP}}$ are fully reversed by saturating levels of intracellular spermine, and is consistent with the absence of any increase of $\mathrm{Na}^{+}$channel expression. Second, we found that the relief of $I_{\mathrm{NaP}}$ located in the proximal dendrites from polyamine-dependent inhibition boosts the summation of synchronous excitatory input in chronic epilepsy.

Dendritic summation of synchronous input patterns in CA1 pyramidal cells is known to be controlled by dendritic voltagegated $\mathrm{Na}^{+}$channels (Magee and Johnston, 1995; Lipowsky et al., 1996; Colbert et al., 1997; Jung et al., 1997), which exhibit specific biophysical properties distinct from somatic channels (Colbert et al., 1997; Jung et al., 1997; Remy et al., 2009). In addition, persistent $\mathrm{Na}^{+}$channels have been detected in dendrites, for instance, in entorhinal cortex principal neurons (Magistretti et al., 1999), as well as in CA1 pyramidal neurons (Lipowsky et al., 1996), and have been suggested to amplify EPSPs in the latter cell type (Lipowsky et al., 1996). Regardless of the molecular identity, our results suggest that the increase in $I_{\mathrm{NaP}}$ leads to a boosting of EPSPs generated by synchronous input patterns in chronic epilepsy. The absence of any significant effect of spermine on unitary EPSP properties likely reflects the fact that unitary EPSPs do not attain sufficient depolarization to activate $I_{\mathrm{NaP}}$. However, it should be noted that the spatial resolution of focal drug applications is relatively low. Thus, although our focal TTX application 
A

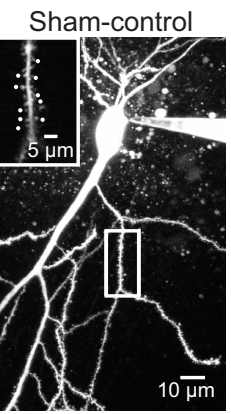

Pilocarpine-treated

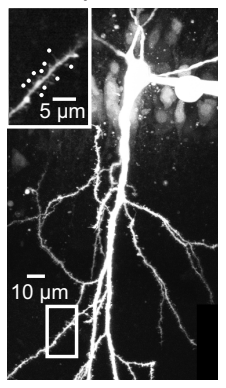

E

Sham-control
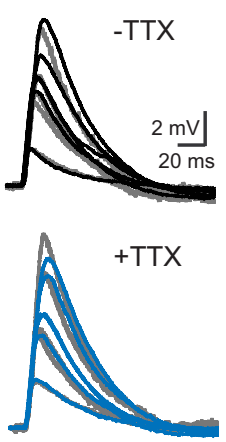

Pilocarpine-treated
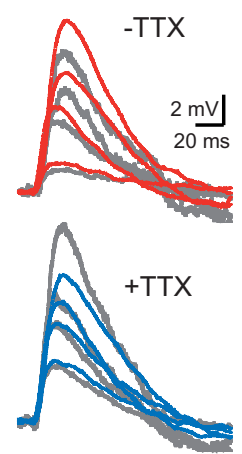

B
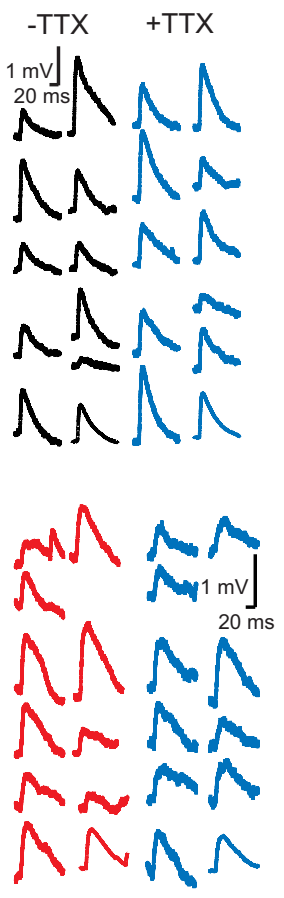

$\mathbf{F}$
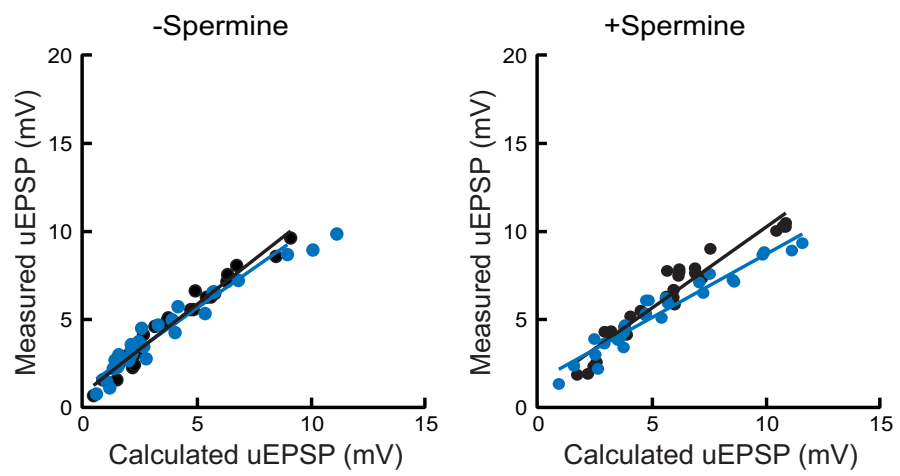

-Spermine

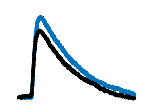

+ Spermine<smiles>C=CCC</smiles>

-Spermine<smiles>CCCC</smiles>

+ Spermine<smiles>C=CCCC</smiles>

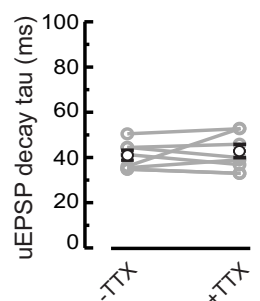

D

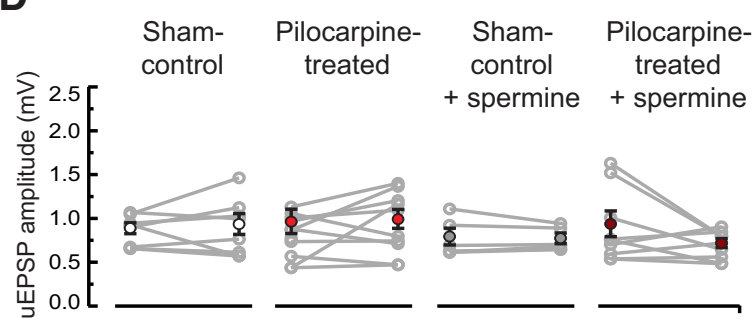

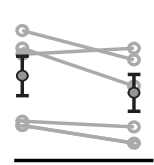
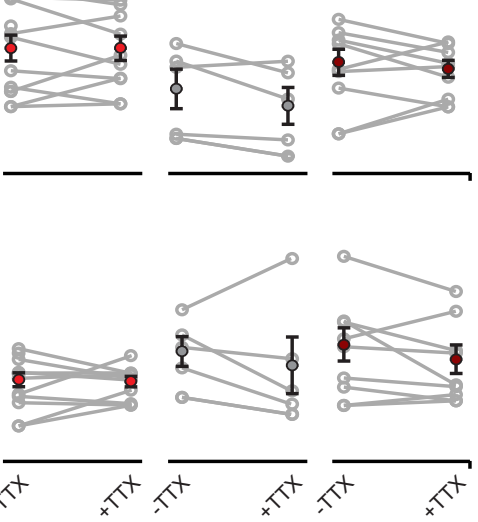

G

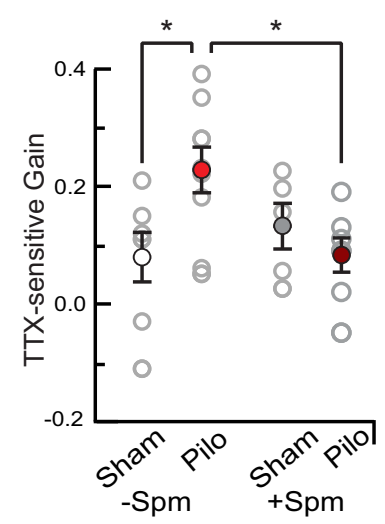

Figure 7. Enhanced $\mathrm{Na}^{+}$channel-mediated dendritic integration in pilocarpine-treated rats is sensitive to spermine. $\boldsymbol{A}$, Two-photon fluorescence images of CA1 pyramidal neurons from sham-control (top) and pilocarpine-treated (bottom) animals. Two-photon glutamate uncaging was performed on apical oblique dendrites (white boxes). Insets, Higher-magnification images with uncaging points indicated. $\boldsymbol{B}$, Individual unitary EPSPs elicited by two-photon glutamate uncaging onto the single spines shown in $\boldsymbol{A}$, in the absence and presence (blue traces) of $0.5 \mu \mathrm{m}$ TTX. $\boldsymbol{C}$, Average uncaging-evoked unitary EPSPs with or without spermine in the intracellular solution, as indicated, and in the absence or presence of TTX (blue traces). D, Properties of unitary EPSPs did not change with the addition of TTX (paired Student's t test, $p>0.1$ for each comparison), and properties were not different between the different experimental groups (one-way ANOVA, $p>0.13$ in all cases). $\boldsymbol{E}$, EPSPs evoked by near-synchronous uncaging onto apical oblique dendritic branches from sham-control (top) and pilocarpine-treated (bottom) animals. Measured compound EPSPs (colored traces) were compared with calculated EPSPs (superimposed gray traces) determined from the arithmetic sum of the corresponding single spine responses (Figure legend continues.) 
data argue for an increase in $I_{\mathrm{NaP}}$ in a proximal dendritic domain, we cannot exclude a contribution of $I_{\mathrm{NaP}}$ more remote from the TTX application site. Notably, somatically located $I_{\mathrm{NaP}}$ could also contribute to EPSP amplification.

How could downregulation of spermine levels cause a local dendritic increase in $I_{\mathrm{NaP}}$ ? We envisage two possibilities. First, the spermine decrease might be local due to increased degradation restricted to within the dendritic compartment. However, the speed of equilibration of fluorescent DEACM-spermine within CA1 neurons suggests that the creation of steep concentration gradients between proximal dendrites and axons is unlikely. It is therefore more likely that the spermine decrease is global, but that the spermine sensitivity of dendritic persistent $\mathrm{Na}^{+}$channels is lower than in other cellular compartments. In this case, a reduction in spermine levels would first affect dendritic channels. This is speculative; the molecular correlate of dendritic $I_{\mathrm{NaP}}$ is currently unknown, although dendritic $\mathrm{Na}_{\mathrm{v}} 1.6$ channels might contribute to this current (Lorincz and Nusser, 2010). Moreover, the subunit-specific sensitivity to spermine block is also unknown. Thus, we cannot finally discriminate between these two hypotheses.

Another consequence of polyamine-dependent upregulation of $I_{\mathrm{NaP}}$ is the increase in spike ADPs and associated intrinsic burst firing. In epileptic CA1 neurons, $I_{\mathrm{NaP}}$-dependent bursting coexists with intrinsic bursting driven by T-type $\mathrm{Ca}^{2+}$ channels (Su et al., 2002; Becker et al., 2008; Chen et al., 2011). Notably, $I_{\mathrm{NaP}^{-}}$ driven bursting is induced at early stages, within several days after SE, and persists for up to 4 months (Chen et al., 2011).

How generalizable is the reduction in spermine levels to other models or even human epilepsy? Interestingly, studies in human specimens obtained from epilepsy surgery have suggested that spermine levels are decreased, whereas the spermidine levels are enhanced in areas of ictal onset (Laschet et al., 1992, 1999). This suggests that the selective reduction in spermine levels described here may also be a feature of the epileptic focus in chronic human epilepsy. In different epilepsy models, diverse results have been reported.

Following kainate-induced seizures, spermine and spermidine content in the hippocampus was reduced, albeit transiently (de Vera et al., 1991). In the electrical kindling model of epilepsy, concentrations of spermidine and spermine were not altered (Hayashi et al., 1989, 1992). In contrast to our findings in the pilocarpine model, studies of kindling and kainate models reported robust increases of putrescine (Hayashi et al., 1989, 1992; de Vera et al., 2002). This discrepancy may be due to differences in the expression of enzymes regulating polyamine content. For instance, seizure activity induced electrically, by kainate, or by electrolytic lesions in the hippocampus causes a robust induction of the synthesizing enzyme ODC that seems to be transient in some preparations (Baudry et al., 1986; Arai et al., 1990; Zawia

\footnotetext{
(Figure legend continued.) (see $\boldsymbol{B}$ ). $\boldsymbol{F}$, Plots of the measured versus calculated EPSP amplitudes under the indicated condition. Left panels, From data shown in $\boldsymbol{E}$ obtained in the absence of intracellular spermine. Solid lines indicate fits to the linear portion to determine gain. Application of TTX (blue circles) reveals a TTX-sensitive component to the gain in pilocarpine-treated animals. Right panels, Measured versus calculated EPSP amplitudes for sham-control (top) and pilocarpine-treated (bottom) animals with intracellular application of spermine. G, Summary data of TTX-sensitive gain component under the indicated condition. The TTX-sensitive component was increased following pilocarpine treatment, compared with sham-control, but was reversed to control levels with the intracellular application of spermine $\left(F_{(3,28)}=4.87, p=\right.$ 0.0075 ). *Statistically significant differences (one-way ANOVA followed by Newman-Keul's multiple-comparison test with $p<0.05$ ).
}

$\leftarrow$ and Bondy, 1990). We also observed this increase at early, but not at chronic stages of epileptogenesis, while a robust increase in SSAT was still present. It could thus be that differential temporal regulation patterns of enzymes may account for differences in the amounts of different polyamines. Aside from the regulation of $I_{\mathrm{NaP}}$, polyamines also modulate other ion channels. For instance, intracellular spermine and spermidine contribute to the rectification of inwardly rectifying $\mathrm{K}^{+}$channels (Ficker et al., 1994; Lopatin et al., 1994; Fakler et al., 1995). Furthermore, intracellular polyamines block $\mathrm{Ca}^{2+}$-permeable AMPA and kainate receptors (Bowie and Mayer, 1995; Kamboj et al., 1995; Koh et al., 1995). Thus, in addition to the facilitatory effects on $I_{\mathrm{NaP}}$, loss of block of these excitatory receptors might also occur in epileptic tissue and contribute to neuronal hyperexcitability. This is particularly true because, in some models of epilepsy, GluR2 subunits are downregulated, giving rise to $\mathrm{Ca}^{2+}$-permeable AMPARs (Friedman et al., 1994; Grooms et al., 2000).

Given that reduced spermine levels enhance dendritic boosting of excitatory synaptic inputs and intrinsic bursting, it might be desirable to revert intracellular spermine in epileptic tissue to normal levels. It should be noted, however, that extracellularly applied polyamines exert convulsant, rather than anticonvulsant, actions. Thus, microinjection of polyamines into the brain induced cortical epileptiform activity (De Sarro et al., 1993) and fatal seizures at higher doses (Doyle and Shaw, 1998; Doyle et al., 2005). Moreover, spermidine treatment increased chemically induced seizure propensity in vivo (Stojanović et al., 2010). Likewise, extracellular application of spermine to hippocampal slices augmented low- $\mathrm{Mg}^{2+}$-induced epileptiform activity (Kirby and Shaw, 2005), an effect that may be due to spermine enhancement of NMDA receptor-mediated currents (Williams et al., 1990). Thus, extracellular supplementation of spermine may not be a promising strategy in chronic epilepsy. An alternative, more feasible approach would be the application of inhibitors of SSAT, the enzyme that is significantly upregulated in chronically epileptic animals. SSAT is being explored as a therapeutic target for other disorders, and design of compounds modulating this protein is under way (Bewley et al., 2006). Polyamine analogs that potently inhibit SSAT activity are available already (Porter et al., 1991; Wu et al., 1996).

The relevance of spermine-dependent modulation of sodium channels for epileptogenesis is still unclear. However, previous studies have established intrinsic bursting as a key mechanism for epileptogenesis (Becker et al., 2008; Doeser et al., 2015). These studies have also shown that genetic or pharmacologic inhibition of the T-type $\mathrm{Ca}^{2+}$ channel-dependent bursting prevents the development of chronic epilepsy. Both $I_{\mathrm{NaP}}$ and $\mathrm{Ca}^{2+}$ channeldependent burst mechanisms coexist in epileptic CA1 pyramidal neurons (Yue et al., 2005). Therefore, it is possible that strategies targeting $I_{\mathrm{NaP}}$ upregulation might also be promising to inhibit epileptogenesis.

In conclusion, we demonstrate, in a model of chronic epilepsy, that the upregulation of dendritic $I_{\mathrm{NaP}}$ in CA1 pyramidal cells, leading to enhanced proximal dendritic excitability and intrinsic bursting, is due to a novel post-transcriptional polyaminedependent mechanism.

\section{References}

Andreasen M, Lambert JD (1999) Somatic amplification of distally generated subthreshold EPSPs in rat hippocampal pyramidal neurones. J Physiol 519:85-100. CrossRef Medline

Arai A, Baudry M, Staubli U, Lynch G, Gall C (1990) Induction of ornithine decarboxylase by subseizure stimulation in the hippocampus in vivo. Brain Res Mol Brain Res 7:167-169. CrossRef Medline 
Azouz R, Jensen MS, Yaari Y (1996) Ionic basis of spike after-depolarization and burst generation in adult rat hippocampal CA1 pyramidal cells. J Physiol 492:211-223. CrossRef Medline

Baudry M, Lynch G, Gall C (1986) Induction of ornithine decarboxylase as a possible mediator of seizure-elicited changes in genomic expression in rat hippocampus. J Neurosci 6:3430-3435. Medline

Beck H, Yaari Y (2008) Plasticity of intrinsic neuronal properties in CNS disorders. Nat Rev Neurosci 9:357-369. CrossRef Medline

Becker AJ, Pitsch J, Sochivko D, Opitz T, Staniek M, Chen CC, Campbell KP, Schoch S, Yaari Y, Beck H (2008) Transcriptional upregulation of $\mathrm{Ca}_{\mathrm{v}} 3.2$ mediates epileptogenesis in the pilocarpine model of epilepsy. J Neurosci 28:13341-13353. CrossRef Medline

Bernard C, Anderson A, Becker A, Poolos NP, Beck H, Johnston D (2004) Acquired dendritic channelopathy in temporal lobe epilepsy. Science 305: 532-535. CrossRef Medline

Bewley MC, Graziano V, Jiang J, Matz E, Studier FW, Pegg AE, Coleman CS, Flanagan JM (2006) Structures of wild-type and mutant human spermidine/spermine N1-acetyltransferase, a potential therapeutic drug target. Proc Natl Acad Sci U S A 103:2063-2068. CrossRef Medline

Bowie D, Mayer ML (1995) Inward rectification of both AMPA and kainate subtype glutamate receptors generated by polyamine-mediated ion channel block. Neuron 15:453-462. CrossRef Medline

Chen J, Sochivko D, Beck H, Marechal D, Wiestler OD, Becker AJ (2001) Activity-induced expression of common reference genes in individual CNS neurons. Lab Invest 81:913-916. CrossRef Medline

Chen S, Su H, Yue C, Remy S, Royeck M, Sochivko D, Opitz T, Beck H, Yaari $Y$ (2011) An increase in persistent sodium current contributes to intrinsic neuronal bursting after status epilepticus. J Neurophysiol 105:117129. CrossRef Medline

Colbert CM, Magee JC, Hoffman DA, Johnston D (1997) Slow recovery from inactivation of $\mathrm{Na}^{+}$channels underlies the activity-dependent attenuation of dendritic action potentials in hippocampal CA1 pyramidal neurons. J Neurosci 17:6512-6521. Medline

De Sarro GB, Bagetta G, Spagnolo C, Nisticò G (1993) Antagonists of $\mathrm{N}$-methyl-D-aspartate receptors block seizures induced by putrescine in the deep prepiriform cortex. Neuropharmacology 32:43-50. CrossRef Medline

de Vera N, Artigas F, Serratosa J, Martínez E (1991) Changes in polyamine levels in rat brain after systemic kainic acid administration: relationship to convulsant activity and brain damage. J Neurochem 57:1-8. CrossRef Medline

de Vera N, Camon L, Martínez E (2002) Cerebral distribution of polyamines in kainic acid-induced models of status epilepticus and ataxia in rats: overproduction of putrescine and histological damage. Eur Neuropsychopharmacol 12:397-405. CrossRef Medline

Ditzen C, Varadarajulu J, Czibere L, Gonik M, Targosz BS, Hambsch B, Bettecken T, Kessler MS, Frank E, Bunck M, Teplytska L, Erhardt A, Holsboer F, Müller-Myhsok B, Landgraf R, Turck CW (2010) Proteomic-based genotyping in a mouse model of trait anxiety exposes disease-relevant pathways. Mol Psychiatry 15:702-711. CrossRef Medline

Doeser A, Dickhof G, Reitze M, Uebachs M, Schaub C, Pires NM, Bonifácio MJ, Soares-da-Silva P, Beck H (2015) Targeting pharmacoresistant epilepsy and epileptogenesis with a dual-purpose antiepileptic drug. Brain 138:371-387. CrossRef Medline

Doyle KM, Shaw GG (1998) Investigation of the actions and antagonist activity of some polyamine analogues in vivo. Br J Pharmacol 124:386-390. CrossRef Medline

Doyle KM, Kirby BP, Murphy D, Shaw GG (2005) Effect of L-type calcium channel antagonists on spermine-induced CNS excitation in vivo. Neurosci Lett 380:247-251. CrossRef Medline

Fakler B, Brändle U, Glowatzki E, Weidemann S, Zenner HP, Ruppersberg JP (1995) Strong voltage-dependent inward rectification of inward rectifier $\mathrm{K}^{+}$channels is caused by intracellular spermine. Cell 80:149-154. CrossRef Medline

Ficker E, Taglialatela M, Wible BA, Henley CM, Brown AM (1994) Spermine and spermidine as gating molecules for inward rectifier $\mathrm{K}^{+}$channels. Science 266:1068-1072. CrossRef Medline

Fink L, Seeger W, Ermert L, Hänze J, Stahl U, Grimminger F, Kummer W, Bohle RM (1998) Real-time quantitative RT-PCR after laser-assisted cell picking. Nat Med 4:1329-1333. CrossRef Medline

Friedman LK, Pellegrini-Giampietro DE, Sperber EF, Bennett MV, Moshé SL, Zukin RS (1994) Kainate-induced status epilepticus alters glutamate and $\mathrm{GABA}_{\mathrm{A}}$ receptor gene expression in adult rat hippocampus: an in situ hybridization study. J Neurosci 14:2697-2707. Medline

Grooms SY, Opitz T, Bennett MV, Zukin RS (2000) Status epilepticus decreases glutamate receptor $2 \mathrm{mRNA}$ and protein expression in hippocampal pyramidal cells before neuronal death. Proc Natl Acad Sci U S A 97: 3631-3636. CrossRef Medline

Häusser M, Spruston N, Stuart GJ (2000) Diversity and dynamics of dendritic signaling. Science 290:739-744. CrossRef Medline

Hayashi Y, Hattori Y, Moriwaki A, Saeki K, Hori Y (1989) Changes in polyamine concentrations in amygdaloid-kindled rats. J Neurochem 53:986988. CrossRef Medline

Hayashi Y, Hattori Y, Hori Y (1992) Involvement of putrescine in the development of kindled seizure in rats. J Neurochem 58:562-566. CrossRef Medline

Huang CJ, Moczydlowski E (2001) Cytoplasmic polyamines as permeant blockers and modulators of the voltage-gated sodium channel. Biophys J 80:1262-1279. CrossRef Medline

Jensen MS, Azouz R, Yaari Y (1996) Spike after-depolarization and burst generation in adult rat hippocampal CA1 pyramidal cells. J Physiol 492: 199-210. CrossRef Medline

Johnston D, Magee JC, Colbert CM, Cristie BR (1996) Active properties of neuronal dendrites. Annu Rev Neurosci 19:165-186. CrossRef Medline

Jung HY, Mickus T, Spruston N (1997) Prolonged sodium channel inactivation contributes to dendritic action potential attenuation in hippocampal pyramidal neurons. J Neurosci 17:6639-6646. Medline

Jung S, Jones TD, Lugo JN Jr, Sheerin AH, Miller JW, D’Ambrosio R, Anderson AE, Poolos NP (2007) Progressive dendritic HCN channelopathy during epileptogenesis in the rat pilocarpine model of epilepsy. J Neurosci 27:13012-13021. CrossRef Medline

Jung S, Bullis JB, Lau IH, Jones TD, Warner LN, Poolos NP (2010) Downregulation of dendritic HCN channel gating in epilepsy is mediated by altered phosphorylation signaling. J Neurosci 30:6678-6688. CrossRef Medline

Jung S, Warner LN, Pitsch J, Becker AJ, Poolos NP (2011) Rapid loss of dendritic HCN channel expression in hippocampal pyramidal neurons following status epilepticus. J Neurosci 31:14291-14295. CrossRef Medline

Kamboj SK, Swanson GT, Cull-Candy SG (1995) Intracellular spermine confers rectification on rat calcium-permeable AMPA and kainate receptors. J Physiol 486:297-303. CrossRef Medline

Kirby BP, Shaw GG (2005) Effect of spermine and N1-dansyl-spermine on epileptiform activity in mouse cortical slices. Eur J Pharmacol 524:53-59. CrossRef Medline

Koh DS, Burnashev N, Jonas P (1995) Block of native $\mathrm{Ca}^{2+}$-permeable AMPA receptors in rat brain by intracellular polyamines generates double rectification. J Physiol 486:305-312. CrossRef Medline

Laschet J, Trottier S, Grisar T, Leviel V (1992) Polyamine metabolism in epileptic cortex. Epilepsy Res 12:151-156. CrossRef Medline

Laschet J, Trottier S, Leviel V, Guibert B, Bansard JY, Chauvel P, Bureau M (1999) Heterogeneous distribution of polyamines in temporal lobe epilepsy. Epilepsy Res 35:161-172. CrossRef Medline

Lipowsky R, Gillessen T, Alzheimer C (1996) Dendritic $\mathrm{Na}^{+}$channels amplify EPSPs in hippocampal CA1 pyramidal cells. J Neurophysiol 76: 2181-2191. Medline

Lopatin AN, Makhina EN, Nichols CG (1994) Potassium channel block by cytoplasmic polyamines as the mechanism of intrinsic rectification. Nature 372:366-369. CrossRef Medline

Lorincz A, Nusser Z (2010) Molecular identity of dendritic voltage-gated sodium channels. Science 328:906-909. CrossRef Medline

Losonczy A, Magee JC (2006) Integrative properties of radial oblique dendrites in hippocampal CA1 pyramidal neurons. Neuron 50:291-307. CrossRef Medline

Losonczy A, Makara JK, Magee JC (2008) Compartmentalized dendritic plasticity and input feature storage in neurons. Nature 452:436-441. CrossRef Medline

Magee JC (2000) Dendritic integration of excitatory synaptic input. Nat Rev Neurosci 1:181-190. CrossRef Medline

Magee JC, Johnston D (1995) Synaptic activation of voltage-gated channels in the dendrites of hippocampal pyramidal neurons. Science 268:301304. CrossRef Medline

Magistretti J, Ragsdale DS, Alonso A (1999) Direct demonstration of persis- 
tent $\mathrm{Na}^{+}$channel activity in dendritic processes of mammalian cortical neurones. J Physiol 521:629-636. CrossRef Medline

Porter CW, Ganis B, Libby PR, Bergeron RJ (1991) Correlations between polyamine analogue-induced increases in spermidine/spermine N1acetyltransferase activity, polyamine pool depletion, and growth inhibition in human melanoma cell lines. Cancer Res 51:3715-3720. Medline

Remy S, Csicsvari J, Beck H (2009) Activity-dependent control of neuronal output by local and global dendritic spike attenuation. Neuron 61:906916. CrossRef Medline

Sanabria ERG, Su H, Yaari Y (2001) Initiation of network bursts by $\mathrm{Ca}^{2+}$ dependent intrinsic bursting in the rat pilocarpine model of temporal lobe epilepsy. J Physiol 532:205-216. CrossRef Medline

Seven I, Weinrich T, Gränz M, Grünewald C, Brüss S, Krstić I, Prisner TF, Heckel A, Göbel MW (2014) Photolabile protecting groups for nitroxide spin labels. Eur J Organic Chem 19:4037-4043.

Shah MM, Anderson AE, Leung V, Lin X, Johnston D (2004) Seizureinduced plasticity of $\mathrm{h}$ channels in entorhinal cortical layer III pyramidal neurons. Neuron 44:495-508. CrossRef Medline

Spruston N (2008) Pyramidal neurons: dendritic structure and synaptic integration. Nat Rev Neurosci 9:206-221. CrossRef Medline

Stojanović I, Jelenkoviæ A, Stevanoviæ I, Pavloviæ D, Bjelakoviæ G, JevtoviæStoimenov T (2010) Spermidine influence on the nitric oxide synthase and arginase activity relationship during experimentally induced seizures. J Basic Clin Physiol Pharmacol 21:169-185. Medline

Su H, Sochivko D, Becker A, Chen J, Jiang Y, Yaari Y, Beck H (2002) Upregulation of a T-Type $\mathrm{Ca}^{2+}$ channel causes a long-lasting modification of neuronal firing mode after status epilepticus. J Neurosci 22:3645-3655. Medline
Thome C, Kelly T, Yanez A, Schultz C, Engelhardt M, Cambridge SB, Both M, Draguhn A, Beck H, Egorov AV (2014) Axon-carrying dendrites convey privileged synaptic input in hippocampal neurons. Neuron 83: 1418-1430. CrossRef Medline

Turski WA, Cavalheiro EA, Schwarz M, Czuczwar SJ, Kleinrok Z, Turski L (1983) Limbic seizures produced by pilocarpine in rats: behavioural, electroencephalographic and neuropathological study. Behav Brain Res 9:315-335. CrossRef Medline

Williams K, Dawson VL, Romano C, Dichter MA, Molinoff PB (1990) Characterization of polyamines having agonist, antagonist, and inverse agonist effects at the polyamine recognition site of the NMDA receptor. Neuron 5:199-208. CrossRef Medline

Wu R, Saab NH, Huang H, Wiest L, Pegg AE, Casero RA Jr, Woster PM (1996) Synthesis and evaluation of a polyamine phosphinate and phosphonamidate as transition-state analogue inhibitors of spermidine/ spermine-N1-acetyltransferase. Bioorg Med Chem 4:825-836. CrossRef Medline

Yaari Y, Yue C, Su H (2007) Recruitment of apical dendritic T-Type $\mathrm{Ca}^{2+}$ channels by backpropagating spikes underlies de novo intrinsic bursting in hippocampal epileptogenesis. J Physiol 580:435-450. CrossRef Medline

Yue C, Remy S, Su H, Beck H, Yaari Y (2005) Proximal persistent $\mathrm{Na}^{+}$ channels drive spike afterdepolarizations and associated bursting in adult CA1 pyramidal cells. J Neurosci 25:9704-9720. CrossRef Medline

Zawia NH, Bondy SC (1990) Electrically stimulated rapid gene expression in the brain: ornithine decarboxylase and c-fos. Mol Brain Res 7:243-247. CrossRef Medline 